\title{
Revisiting Reinhart \& Rogoff after the Crisis: A Time Series Perspective
}

DOI:

10.1093/cje/bez009

Link to publication record in Manchester Research Explorer

\section{Citation for published version (APA):}

Amann, J., \& Middleditch, P. (2020). Revisiting Reinhart \& Rogoff after the Crisis: A Time Series Perspective. Cambridge Journal of Economics, 44(2), 343-370. https://doi.org/10.1093/cje/bez009

\section{Published in:}

Cambridge Journal of Economics

\section{Citing this paper}

Please note that where the full-text provided on Manchester Research Explorer is the Author Accepted Manuscript or Proof version this may differ from the final Published version. If citing, it is advised that you check and use the publisher's definitive version.

\section{General rights}

Copyright and moral rights for the publications made accessible in the Research Explorer are retained by the authors and/or other copyright owners and it is a condition of accessing publications that users recognise and abide by the legal requirements associated with these rights.

\section{Takedown policy}

If you believe that this document breaches copyright please refer to the University of Manchester's Takedown Procedures [http://man.ac.uk/04Y6Bo] or contact uml.scholarlycommunications@manchester.ac.uk providing relevant details, so we can investigate your claim.

\section{OPEN ACCESS}




\title{
REVISITING REINHART \& ROGOFF AFTER THE CRISIS: A TIME SERIES PERSPECTIVE
}

\begin{abstract}
This paper offers a straightforward and descriptive contribution to the recent and busy debate on fiscal discipline made popular by the seminal Reinhart and Rogoff (2010) paper, after policymakers have sought foundation and justification for a policy known as austerity measures, following on from the sovereign debt crisis of 2010. We revisit the debate on whether or not higher debt levels impede growth rates and offer a time series perspective of a corrected data set and a more recent higher frequency source. We find that with further hindsight, and from a time series perspective, there is little to no support for the view that higher levels of debt cause reductions in economic activity. In contrast to Reinhart and Rogoff (2010), we suggest that economic slumps tend to cause debt build-ups rather than vice versa.
\end{abstract}

Keywords: Austerity, Macroeconomic Policy, Fiscal Policy

JEL Classification: E60, E62, E65

\section{Introduction}

In the aftermath of the global financial crisis we revisit the popular debate on fiscal discipline that has become crystallised around a controversial study by Reinhart and Rogoff (2010), the findings of which suggest that countries with higher debt/GDP ratios (of above $90 \%$ ) are associated with impeded growth rates. Our contribution to this debate is a time series analysis that makes use of a more recent and higher frequency data source, obtained from the OECD, alongside a corrected version of the original data from Herndon et al. (2014), responsible for previous implications that austerity measures can be implemented to reactivate an economy experiencing a deep recession.

In contrast to the majority of the literature on the debt growth nexus, our approach is one that makes use of a deliberately simplistic time series perspective. We provide an exploratory and descriptive presentation of the facts, in a similar way to Reinhart et al (2012) and some of the earlier literature surrounding the Reinhart and Rogoff (2010) findings. We do so alongside a comprehensive debt threshold analysis which we suggest is perfectly adequate for the purpose of providing further evidence to this busy debate, offering an alternative view on a topic that has been the subject of wide controversy inside and beyond the field of economics. We consider our contribution a worthy addition to the 
literature, given that more sophisticated empirical studies have so far found inconclusive support for the Reinhart and Rogoff (2010) 'debt-threshold' hypothesis and are oftentimes confronted with severe empirical challenge. We find little to no evidence to support the view that higher public debt levels dampen economic growth, and rather the converse case, where depressions in output lead to higher debt, is more likely in line with other papers that have stressed the reverse-causal nature of economic growth and public debt (PuenteAjovín and Sanso-Navarro, 2015; Lof and Malinen, 2014 and Irons and Bivens, 2010).

The financial crisis of 2007 brought an extraordinary slump in economic activity and significant increases in gross government debt for many western developed economies. Increased borrowing and the need to recapitalise financial institutions left governments across Europe vulnerable in terms of borrowing ability, and consequently facing sovereign debt crises. Even though the causality linkage between public debt and economic growth is rather complex, and not yet fully understood, it is believed to be best described through a bidirectional relationship: In conventional views, public debt build-ups through increases in public spending, are assumed to have a positive short-run expansionary effect on demand, but also a crowding out of capital and thus lower economic growth in the medium to long-run.

On the other hand, low economic growth is also likely to induce higher public debt. Given the rise in gross government debt figures across advanced nations, it is of little surprise that scholars have tried to find an answer to the question of whether or not economic growth can be stifled by excessive public debt. Up until the unfolding of the financial crisis, there had been little research in this area. An influential study by Reinhart and Rogoff (2010) found a link between public debt and economic growth with evidence of a debt-threshold (of 90\%) at which economic growth is reduced by half. This study is not alone in the support of the debt-threshold hypothesis, see Cecchetti et al. (2011), Casni et al. (2014), Baum et al. (2013), Woo and Kumar (2015) or Caner et al. (2010) for examples.

In an environment of surging public debt and crumbling growth rates, international organisations and policymakers have found their own interpretation of studies such as this to legitimise rigorous public spending cuts, commonly referred to as austerity measures; a term used to describe a form of fiscal discipline, and discussed in detail by Konzelmann (2014). Whereas the effectiveness and legitimacy of austerity measures are widely discussed in the public, economic and political arenas, the findings in Reinhart and Rogoff (2010) have also provoked rigorous discussion in the field of applied economics, including contradictions by Chang and Chiang (2012) and Panizza and Presbitero (2014a), and serious technical challenges to the validity of the methodology, such as Herndon et al. (2014), Kourtellos et al. (2013) and Minea and Parent (2012).

In this study we re-visit the busy debate on the causal relationship between economic growth and sovereign debt by offering a two-fold contribution: In Section 2, we compartmentalise the literature using the most recent empirical contributions surrounding the field of fiscal discipline, discussing empirically motivated work in the context of correlation, causality, endogeneity and cross-country heterogeneity. We argue that the field 
has yet to present a coherent framework with consistent evidence for the existence of a 'debt-threshold' or a strong case for a significant and negative causal link between public debt and economic growth. In Section 3, we emphasise the need for a more careful evaluation in the context of heterogeneity patterns and threshold effects via a simple visual analysis of two comprehensive data sets: We employ the corrected Reinhart and Rogoff (2010) data provided by Herndon et al. (2014) and a more recent and higher frequency OECD data source to provide a non-parametric and descriptive evaluation of both the potential causal link between the variables as well as the 'debt-threshold' hypothesis.

A key advantage of extending our analysis to encompass the higher frequency data source is the additional ability to consider higher frequency information including intra annual fluctuations; although one might question the usefulness of this additional measure, given the notorious persistence in debt and growth dynamics generally. In the context of the Reinhart and Rogoff (2010) study, the usefulness arises from the time period in question. The OECD sample benefits from increased scope and captures a period of increased volatility witnessed since 2009. We therefore suggest that the perspective provided by the OECD quarterly data is an enhanced one.

The use of lower frequency data can lead to confusion over the direction of causality, a key issue in the context of this debate over the relationship between debt and growth. The causal relationship can appear immediate in lower frequency data, and this may explain the conflicting findings in the debt growth nexus literature, underlining the value of exploratory analyses such as this study. By comparing different frequencies with varying data coverage we illustrate a robustness in our findings that holds despite some data discrepancies across both sets. ${ }^{1}$ Given that debt levels have risen consistently from the beginning of the financial crisis, and for many countries surpassing the $90 \%$ mark of the sovereign debt-to-GDP ratio, this study benefits from a longer time series perspective on the correlation between debt levels and economic growth; one which encompasses these crucial debt build-ups in the latter part of the OECD sample. We find consistency across both data sets and provide particular focus and comparison of the period leading up to the financial crisis with that of the period of global recovery, where economic activity has returned to more normal levels.

With the benefit of the extended scope provided by the two different data sets, we illustrate that there is little to no evidence to support for the view that higher public debt levels dampen economic growth. Instead, our findings lend support to those who suggest a reverse causality, where slumps in economic activity are largely responsible for increases in public debt. This becomes obvious as debt build-ups typically proceed economic downturns, a pattern that regularly appears, irrespective of the actual debt level. At the same time, even though actual growth outcomes are shown to be high in volatility, median growth rates for countries above the $90 \%$ threshold are indistinguishable from their lowdebt counterparts.

As debt levels have risen consistently from the beginning of the financial crisis, and for many countries surpassing the $90 \%$ mark of the sovereign debt-to-GDP ratio, this study benefits from a longer and time series perspective on the correlation between debt levels 
and economic growth. With the benefit of extended scope and hindsight, our study finds no clear-cut evidence in favour of the debt-threshold hypothesis. Instead, it lends support to those who suggest a reverse causality, where slumps in economic activity are largely responsible for increases in public debt. Consequently, we conclude that our analysis throws serious doubt over previous findings that austerity measures might assist in the reactivation of an economy from a deep recession.

\section{Relevant Literature}

Within the empirical literature, numerous approaches have been employed in the attempt to shed light on the debt-growth relationship. ${ }^{2}$ Whilst we acknowledge the wider scope of the literature, the purpose of this study is to concentrate on the empirical post-crisis strand which has the 'debt-threshold' hypothesis at its core. We argue that this particular strand of the literature has yet to present a coherent framework with consistent evidence for the existence of a 'debt tipping point' or a strong case of a significant and negative causal link between public debt and economic growth. We show this in the preceding paragraphs using the delineating factors of exploratory evidence, correlation and causality, endogeneity, and cross-country heterogeneity.

\subsection{Exploratory Evidence}

In their influential study Reinhart and Rogoff (2010) suggest a debt threshold of $90 \%$ at which growth is reduced by half for a sample of OECD countries. More precisely, their '[...] main result is that whereas the link between growth and debt seems relatively weak at 'normal' debt levels, median growth rates for countries with public debt over roughly 90 percent of GDP are about one percent lower than otherwise' (Reinhart and Rogoff, 2010 , p. 573). Even if it is clear that association or correlation between two variables by no means implies a causal effect of one variable on the other, the authors are probably over ambitious in arguing that, '[...] when gross external debt reaches 60 percent of GDP, annual growth declines by about two percent; for levels of external debt in excess of 90 percent of GDP, growth rates are roughly cut in half' (Reinhart and Rogoff, 2010, p. 573).

The Reinhart and Rogoff (2010) paper has also sparked controversy through the empirical replication of their study by Herndon et al. (2014) who reported that coding errors, selective data exclusion and unconventional weighting of summary statistics lead to an inaccurate representation of the relationship between public debt and GDP growth for the data sampled. After correcting these deficiencies, the previously reported, extraordinary debt threshold becomes significantly smaller, leading Herndon et al. (2014, p. 278) to conclude that 'policy-makers cannot defend austerity measures on the grounds that public debt levels greater than 90\% of GDP will consistently produce sharp declines in economic growth'. Nonetheless, it would be unjust and rather convenient to hold Reinhart and Rogoff (2010) accountable for the direction into which the public, political or economic debate has been leaning, let alone for the economic consequence of austerity 
itself. Reinhart and Rogoff (2010) might have been the first since 2008 but their findings are not without support; various studies have provided a more formal test of the $90 \%$ 'debtthreshold' hypothesis and have, to some extent, confirmed its existence:

In a literature survey-style paper, Reinhart et al. (2012) extend the analysis of Reinhart and Rogoff (2010) to analyse 'debt overhangs' in advanced economies starting from the year 1800. The authors define 'debt overhangs' as periods where debt-to-GDP ratios (also referred to as D throughout the paper) exceed $90 \%$ for at least five years and compare average GDP growth rates for these regimes. The authors do not address the legitimacy of their $90 \%$ ad-hoc 'debt-threshold' view or their choice of the five-year selection window even though they argue that their results are '[...] reasonably robust to choices other than 90 percent as the critical threshold' (Reinhart et al., 2012, p. 70). What makes the threshold argument problematic in the eyes of the authors of this study is that through their ad-hoc selection rule, Reinhart et al. (2012) identify 26 debt-overhang periods for only 13 out of their sample of 22 advanced countries and furthermore note that '[...] many debt overhangs result from costly wars. There are distinct clusters around World War II and, to a lesser extent, World War I' (Reinhart et al., 2012, p.77, also Figure 1). This leaves the analysis for more recent, public debt overhangs since 1970 for advanced economies to no more than six countries: Belgium (1982-2005), Canada (1992-1999), Greece (1993-2012), Ireland (1983-1993), Italy (1988-2012) and Japan (1995-2012) (Reinhart et al., 2012, Table 2).

Among other studies that have motivated their research using a descriptive and exploratory data analysis, only a few have found quantitatively similar effects. For example, Egert (2013) performs a descriptive analysis of the original Reinhart and Rogoff (2010) data, its corrected counterpart (Herndon et al., 2014) as well as a third data set by Egert (2012) where the author had matched government debt data presented in Reinhart and Rogoff (2010) with growth rates from the Barro and Ursula (2010) data set. In line with the results in Egert (2012), Egert (2013) shows that real GDP growth slows down considerably when the debt-to-GDP ratio surpasses $30 \%$ but also finds no further slowdown for higher debt levels. This observation holds when using lagged levels of central government debt as well as 10-year average growth rates. Furthermore, this study claims that exact instances where public debt of over $90 \%$ slows economic growth are simply not present in the data: the stylised fact of a debt overhang regime appears to be a statistical fallacy (Egert, 2013, p. 18).

Similar to Egert (2012), Minea and Parent (2012) was one of the first papers to investigate the claims made by Reinhart and Rogoff (2010) by compiling an alternative data set which features the same countries as in the original study and resorts to GDP data from Bolt and van Zanden (2014) to calculate the GDP growth rate as well as Abbas et al. (2010) for public debt measures. Minea and Parent (2012) undertake the same empirical analysis based on discrete bins associating pre-defined debt threshold levels of $<30 \%$, $30 \%-60 \%$ and $>90 \%$ with their corresponding growth rates and find a much less pronounced dip for the 'debt overhang' regime. Similar exercises were undertaken by Irons and Bivens (2010), Bell et al. (2015) or Amann and Middleditch (2017) who all use scatterplot techniques of (variations of) Reinhart and Rogoff (2010)'s original data and find little 
to no evidence of a comparably devastating drop in GDP growth rates at or around the 'debt overhang' threshold. The same observation is made by Puente-Ajovín and SansoNavarro (2015) who plot the ten-year average government debt-to-GDP ratio against real GDP growth for 16 OECD countries between 1980 and 2009 or Afonso and Jalles (2013) who plot GDP growth rates against sovereign debt (Afonso and Jalles, 2013, see Figure 1, Panel $b$ for the sub-set of OECD countries). On the other hand, Woo and Kumar (2015, Figure 3) look at 38 advanced and emerging economies over the periods 1970 to 2007 and present evidence suggesting that average five year ahead GDP growth rates are considerably lower for countries with an initial debt-to-GDP ratio above $90 \%$ compared to countries with a ratio of below $30 \%$ across various country groups.

Finally, Pescatori et al. (2014) follow a somewhat different set-up to explore the longrun relationship between debt and growth when plotting the average growth rates of the sets of countries exceeding a varying threshold parameter over a time window of $1,5,10$ and 15 years. The authors conduct their analysis for a sample of 34 countries spanning the period 1875 to 2010 and find no evidence in favour of the 'debt-threshold' hypothesis or a debt-overhang regime with innately different growth dynamics. Rather, they report that the association of debt and growth tends to weaken for higher levels of debt, particularly when controlling for peer country growth rates. The authors also present evidence suggesting that the debt trajectory may be even more important than the actual level of debt to predict future economic growth outcomes.

\subsection{From correlation to causality}

From an empirical point of view, a less sophisticated approach to learn about the relationship between economic growth and sovereign debt would be to investigate the sign and statistical significance of the debt-to-GDP ratio coefficient of the simple linear model

$$
G R_{t+n, t}=\alpha+\beta D_{t}+u_{t}
$$

where $G R_{t+n, t}$ is the percentage growth rate of output between periods $t$ and $t+n$ and $D_{t}$ is the debt-to-GDP ratio (country subscript $i$ suppressed). An immediate issue arising is the obvious endogeneity problem resulting in an estimation bias of

$$
\hat{\beta}=\frac{\beta \sigma_{v}^{2}+\theta \sigma_{u}^{2}}{\sigma_{v}^{2}+\theta^{2} \sigma_{u}^{2}}
$$

which we derive in Appendix C. This concern has been addressed in the literature amongst others by Panizza and Presbitero (2014b), Bell et al. (2015) or Dube (2013). Apart from this algebraic relationship, the endogenous connection between both variables becomes even more illustrative if we consider the fact that some policy interventions may explicitly 
further endogenise both variables: For example, it is widely believed that debt financing can be a useful way to help an economy recover more quickly from a recession and is hence more likely to occur during episodes of particularly low growth. Conversely, austerity advocates have argued that particularly high debt levels have to be brought down in order to allow for a swift economic recovery.

A straight-forward way common within the literature to address this issue is by treating both $G R$ and $D$ as endogenous by means of a vector autoregressive (VAR) model of the form

$$
\begin{aligned}
G R_{t+n, t} & =\alpha+\sum_{l=1}^{p_{D}} \beta_{l} D_{t-l}+\sum_{l=1}^{p_{G R}} \gamma_{l} G R_{t-l}+u_{t} \\
D_{t+n, t} & =\delta+\sum_{l=1}^{p_{G R}} \theta_{l} G R_{t-l}+\sum_{l=1}^{p_{D}} \phi_{i} D_{t-l}+v_{t}
\end{aligned}
$$

where $\left(p_{G R}, p_{G R}\right)$ denotes the selected lag length for the endogenous variables. One can then think of an endogeneity test of past debt-to-GDP ratios on GDP growth as a simple test of non-Granger causality formulated as

$$
H_{0}: \beta_{l}=0 \forall l=1, \ldots, p_{D}
$$

where $\beta_{l}$ are the $p_{D}$ lagged coefficients of $D_{t-l}, l=1, \ldots, p_{D}$, in Equation 3a. A positive sideeffect is that this set-up accounts for the effect of debt-trajectory, which is rarely addressed outside the VAR framework (Dube, 2013; Pescatori et al., 2014). In this context, an interesting point has been raised by Irons and Bivens (2010) who discuss that the traditional crowding out argument is more concerned with the actual flow (deficit) rather than the stock (of debt). Therefore, debt build-ups are rather a symptom than the causal root of stifled economic growth. This rational provides a more theoretical argument for a 'reverse causality' link from low growth to high debt where high deficit spending may be one but not the only driving force of crumbling GDP growth rates. As it turns out, these 'reversely causal' links are readily found in the literature: In a sample of 16 OECD countries spanning 30 years Puente-Ajovín and Sanso-Navarro (2015) apply a panel bootstrap Granger causality test developed by Kónya (2006) which accounts for cross-country heterogeneity as well as cross-sectional dependence. The authors fail to report evidence that government debt Granger causes real GDP growth but find evidence that gross debt is negatively affected by economic growth.

The same implication of 'reverse causality' is found by Lof and Malinen (2014) who employ a VAR analysis to investigate the debt-growth nexus by means of impulseresponse functions for a panel of 20 as well as 10 developed and developing countries for the periods 1905 to 2008 and 1954 to 2008 respectively. As before, the authors find no significant impact on the GDP growth rate when introducing a shock to debt, but a significant negative effect of a GDP shock on debt. By applying the Hsiao (1981) procedure, Gómez-Puig and Sosvilla-Rivero (2015) test for bi-directional Granger 
causality analysis for central and peripheral countries of the European Economic and Monetary Union between 1980 and 2013 with little evidence of a causal relationship between both variables. However, when allowing for endogenously detected break points the authors report evidence of a negative effect of debt on economic growth for some EMU countries, but also a significant effect for some other members. Another study which analyses a Granger causal relationship is Irons and Bivens (2010) who study the debtgrowth nexus for the case of the USA and fail to reject non-Granger causality going from debt to growth but finds significant evidence of a reverse causality link from growth to debt.

Bell et al. (2015) analyse the causality link of growth and debt by means of random coefficients as well as multi-level distributed lag models to capture time and countrydependent heterogeneity. They present empirical evidence of a reverse causality link going from (low) economic growth to (high) public debt, with results that indicate strong patterns of heterogeneity and claim that the aggregated presentation of the debt-growth nexus through 'stylised facts' as in Reinhart and Rogoff (2010) is misleading, due to crosscountry variation. Amann and Middleditch (2017) in a UK specific study, make use of Granger causality and co-integration tests that account for structural breaks and find no empirical support for the hypothesis that fiscal discipline can directly restore economic activity after a recession, or that there is any statistically significant relationship between increasing public debt and growth. By contrast, Afonso and Hauptmeier (2009) analyse the Granger causality relationship between economic growth and the ratio of current primary surplus over GDP as well as the debt-to-GDP ratio. For 20 OECD countries between 1988 and 2001 they report a significant, bi-variate Granger causality relation between the debtto-GDP ratio and GDP growth and add further evidence to the possibility of the presence of country-specific heterogeneity (Afonso and Hauptmeier, 2009, Appendix 1).

One crucial point regarding the above-discussed literature is that even though Granger causality related testing procedures are capable of adequately modelling endogeneity, the issues arising from omitting relevant variables from the model remain. This is shown by Lütkepohl (1982) who argues that causal structures of sub-processes of multivariate stochastic processes do not allow the drawing of a conclusion with regards to the causal structure of the higher dimensional process. Consequently, any Granger causality findings in a subprocess may be due to an omitted variable (and vice-versa) and consequently affect empirical results. Relationships between aggregated variables are highly complex with possible multi-directional statistical connection, feedback loops and two way multi lagged effects all contributing to the realised chain of economic events. What is more, the VAR approach as described in Equation 3 is limited to the linear domain by construction.

As shown in Baek and Brock (1992), such parametric and linear Granger causality tests are found to have low power against certain non-linear alternatives. Even though advances have been made to (endogenously) account for non-linearities and threshold effects (Galvão, 2006) or time-varying coefficients (Christopoulos and León-Ledesma, 2008), to the knowledge of the authors, none of these techniques have been applied to the debt-growth nexus yet. 


\subsection{Endogeneity in a cross-country setting}

An alternative way to address reverse causality is by means of a method involving instrumental variables; though as in many other areas, researchers have found it difficult to identify appropriate or adequately exogenous instruments. Panizza and Presbitero (2014b) instrument the debt-to-GDP ratio with the valuation effect of debt held in foreign currency and exchange rate movements. They find little to no evidence of a debt threshold, arguing against the threshold-view as a justification for fiscal consolidation. However, their instrument of choice has values close to zero with zero variance for France, Germany, Japan, the Netherlands and the United States, borne from the fact that these five countries simply do not hold sovereign debt in foreign currency.

Checherita-Westphal and Rother (2012) investigate the average impact of government debt on per capita GDP growth for twelve Euro area countries spanning the period 1970 to 2008 . Their exogenous instrument for country $i$ is the averaged debt-toGDP ratio of all remaining (12-i) countries; a proposition which may cast doubts in terms of validity: Only if 'there is no strong relationship between debt levels in other Euro areas countries and the per-capita GDP growth rate in one specific country' (ChecheritaWestphal and Rother, 2012, p. 1398) their chosen instrument can be considered adequate. In practise the proposition that there is no connection between the debt-to-GDP ratios and GDP growth rates for a set of countries within a monetary union might be seen as questionable. As rightly pointed out by Panizza and Presbitero (2014b), this is like assuming that under similar absolute debt measures for all countries, GDP of country $i$ is not affected by all remaining countries. Furthermore, the existence of 'debt spill-overs' is far from just a theoretical possibility; for example, in a scenario like the European banking crisis where member countries had to join forces to rescue systemic, trans-national banking conglomerates, it is entirely imaginable that such joint efforts may have carried over to affect the economic performances of all involved countries. The collective bail out of Fortis by Belgium and the Netherlands in September 2008 serves as an illustrative example in this context.

Checherita-Westphal and Rother (2012) also employ endogenous instruments to combat the challenges of endogeneity by means of a GMM estimation framework. In a similar vein, Furceri and Zdzienicka (2012) adopt a two-step GMM-system estimator when analysing the effect of debt, currency and banking on growth for a sample of 154 countries and the period 1970 to 2008. They conclude that debt crises can cause long and persistent losses in output growth and that they may be more harmful for economic growth than the latter two. This approach has proven to be quite popular; see for example Woo and Kumar (2015); Afonso and Jalles (2013); Padoan et al. (2012) who all use GMM alongside more conventional tools such as simple OLS, of panel fixed and random effects (FE \& RE).

Unfortunately, the inclusion of lagged, endogenous instruments may not adequately address the (potential) endogeneity problem in this particular case as this method was initially designed with microeconomic purposes in mind. It is not well-suited for data sets with a relatively small number of cross-sectional observations (Bond, 2002); 
a key feature of macroeconomic data sets. More specifically, difference and system GMM may be severely affected by the problem of weak instruments (Bun and Windmeijer, 2007) which, furthermore, may not be solved by simply introducing more lags to the system, but rather increase the probability of introducing spuriousness (Bazzi and Clemens, 2013). These noteworthy limitations raise doubts with regards to its legitimacy in this context: Panizza and Presbitero (2014b) point to evidence suggesting potential problems with some of the GMM estimation results reported in the literature.

To summarise, empirical efforts to unfold the debt-to-growth relationship through a cross-country framework are challenged by their capability to adequately control for model simultaneity. As far as the IV approach is concerned, valid exogenous instruments are difficult to find and not adequate in most cases while an endogenous instrument set-up may potentially be ill-suited for this empirical exercise. An interesting point is raised by Dube (2013, p. 7) who observes that most papers following a cross-country approach add lagged GDP levels, but hardly ever lagged GDP growth rates as controls to their estimation. He stresses the importance of accounting for the effect of the evolution of growth dynamics to adequately account for reverse causality linkages, as increases in debt are found to have an effect on past but not on future growth figures.

\subsection{Heterogeneity}

Important implications arise around the issue of cross-country heterogeneity. In this context we do not intend to direct the discussion towards the effects of debt on growth with regards to the development stages of country groups. We recognise that there is a wide and distinguished empirical literature indicating that both the composition of debt and the general impact of debt overhangs seem to affect developing countries more than their developed counterparts; however, a more pronounced survey of this field would go beyond the scope of this paper. Instead, we expand on the observation by Eberhardt and Presbitero (2015) who apply the same visual analysis as Reinhart and Rogoff (2010) using discrete bins as well as a fractional polynomial regression of GDP growth against the debt-to-GDP ratio thereby producing visual evidence in general support of the $90 \%$ threshold hypothesis.

This is an important interjection: A model that focuses its analysis and identification on significant changes in parameters, assumed to be the same across all crosssectional units as it is the case for most panel-styled papers of this literature, does not necessarily imply that the observed aggregated pattern holds true for the majority of the units on an individual level as well. In other words, recorded non-linearities may simply be spuriously occurring results of aggregating cross-sectional heterogeneities rather than of systemic nature (Haque et al., 1999). Eberhardt and Presbitero (2015) also point out that underlying and unobserved factors might have a significant effect on the estimation outcomes and crucially depend on the data set used for the analysis. Particularly for a set of homogeneous and strongly interconnected entities, cross-sectional dependence may severely bias estimation results. Using a dynamic Common Correlated Effects (CCE) Mean Group estimator which allows for varying country-level coefficients they find no empirical evidence of a common cross-country debt threshold. 
The importance of accounting for cross-country heterogeneity is also stressed by Chudik et al. (2015) who provide evidence of cross-sectional heterogeneity of the 'debtthreshold' hypothesis in a dynamic, heterogeneous panel set-up. The authors provide threshold estimates of between 60 to 80 percent for the full sample as well as 80 percent for the advanced economies and between 30 to 60 percent for developing countries respectively when not accounting for unobserved common factors. Their cross-sectionally augmented models fail to reject the hypothesis of no simple debt threshold. Consequently, they draw no conclusive picture of a significant debt threshold for either advanced or developing economies.

Further evidence on the existence of cross-country heterogeneity in debt effects are also made in the VAR framework by Gómez-Puig and Sosvilla-Rivero (2015). The authors find no evidence of Granger causality between debt and economic growth when analysing a sample up to 2009. However, when allowing for endogenously detected break points the authors report evidence of a significant, negative Granger causality for five of the eleven countries for the period after the breaks with potential threshold levels ranging from 53\% to $103 \%$ but also identify another set of other countries which retain their positive Granger causality relationship of D to GR even after the crisis. The authors thus show how crosscountry heterogeneity is of fundamental importance even when looking at a relatively homogeneous group of (EMU) countries.

The observation of heterogeneity has also been raised on the inter-temporal front: Exemplarily, Minea and Parent (2012) acknowledge the existence of countries with high public debt ratios (above 115\%) and high economic growth; particularly in the post WWII period and last decade of the 20th century. As discussed before, Baum et al. (2013) find evidence of a considerable increase in the significant debt threshold (from 66 to 72 and 96 percent for the non-dynamic and dynamic panel respectively) if the crisis years 2008 to 2010 are added to the analysis. Including the period 1980 to 1989 results in insignificant threshold estimates.

\subsection{Summary}

In this section we have surveyed a wide and contradictory field of academic research concerned with the importance of public debt for economic activity. We have focused on the most consistent and well developed body of 'debt literature' in advanced economies in terms of modelling choices. Our reading of the literature is that the debt-growth relationship is both more complex and heterogeneous, when considered across countries and time periods, than initially assumed. What is more, it also raises the question as to whether gross debt is indeed the correct measure for this investigation in the first place, because of its inherent inability to consider the cross-sectional heterogeneity of national debt compositions. In other words, if there is a common factor in the composed measure of sovereign debt that stifles economic growth, the current practice of analysing (aggregated) sovereign gross debt makes it impossible to disentangle such a force in the 
same way that an aggregation might lead to a potentially misleading formulation of the 'debt-threshold' hypothesis.

One interesting characteristic of the debate, to date, is that as the argument develops over time the consensus appears to be reversing, with later studies tending to disagree with the existence of the debt threshold. We can see this through the increase in studies finding against the debt threshold nexus, or failing to reject the reverse causality hypothesis since the intervention by Herndon (2014); a study that appears to have attracted the attention of more technical treatments capable of reversing the earlier findings in favour of the debt threshold when allowing for issues such as cross country heterogeneity and parameter instability. Until more accentuated data is available, researchers are required to make an educated guess as to how homogeneous or heterogeneous country-level data may allow for a clear aggregated analysis of the debt-growth nexus. We intend to address this in the second part of the paper, where we look at two separate data sets and discuss both common and heterogeneous patterns in the data, before exploring ways to identify debt tipping points.

\section{Exploratory Data Analysis: A Time-series Perspective}

In this section we revisit the central claims made in Reinhart and Rogoff (2010) by employing a novel exploratory approach to visually disentangle the linkage between economic growth and public debt. We do this by using the corrected Reinhart and Rogoff (2010) data set following Herndon et al. (2014) which we contrast with up-to-date and higher-frequency OECD data.

We offer a deliberately uncomplicated contradiction to the findings of Reinhart and Rogoff (2010) and the earlier supporting literature, by employing basic visual and exploratory techniques, in a similar way to Reinhart et al (2012), allowing us to highlight channels and directions of causality, that might remain difficult to disentangle in more sophisticated empirical techniques. In doing so; we use an approach that we hope will facilitate wider access to this important debate, beyond the field of economics. Our goal is to develop insights regarding the time-dependent causality pattern of debt and growth, their structural nature as well as any potential threshold effects of debt by comparing the patterns of the same set of countries and periods at different frequencies. We have chosen to compare the two different data sets, to mitigate possible bias on previous studies caused by the loss of high frequency information and also to see how the marked increase in volatility for the debt to GDP ratio since 2009 affects our results for the k-period-ahead average growth rate for various debt thresholds.

\subsection{Inter-temporal Linkage of Debt and Growth}

In order to evaluate the relationship between public debt and time we introduce three regimes for debt and growth which we define based on the findings in the literature: As for sovereign debt, we chose the first regime postulated by Reinhart and Rogoff (2010) with a 
gross government debt-to-GDP ratio of above $90 \%$ and following the empirical literature by defining a middle regime for ratios ranging between $60 \%$ and $90 \%$ of GDP and a third debt regime of below $60 \%$. Furthermore, we define three growth regimes associated with GDP growth rates of above $2 \%$, between $2 \%$ and $0 \%$ as well as below $0 \%$.

Figure 1: GDP Growth, Reinhart and Rogoff (2010) data, 1946 to 2009

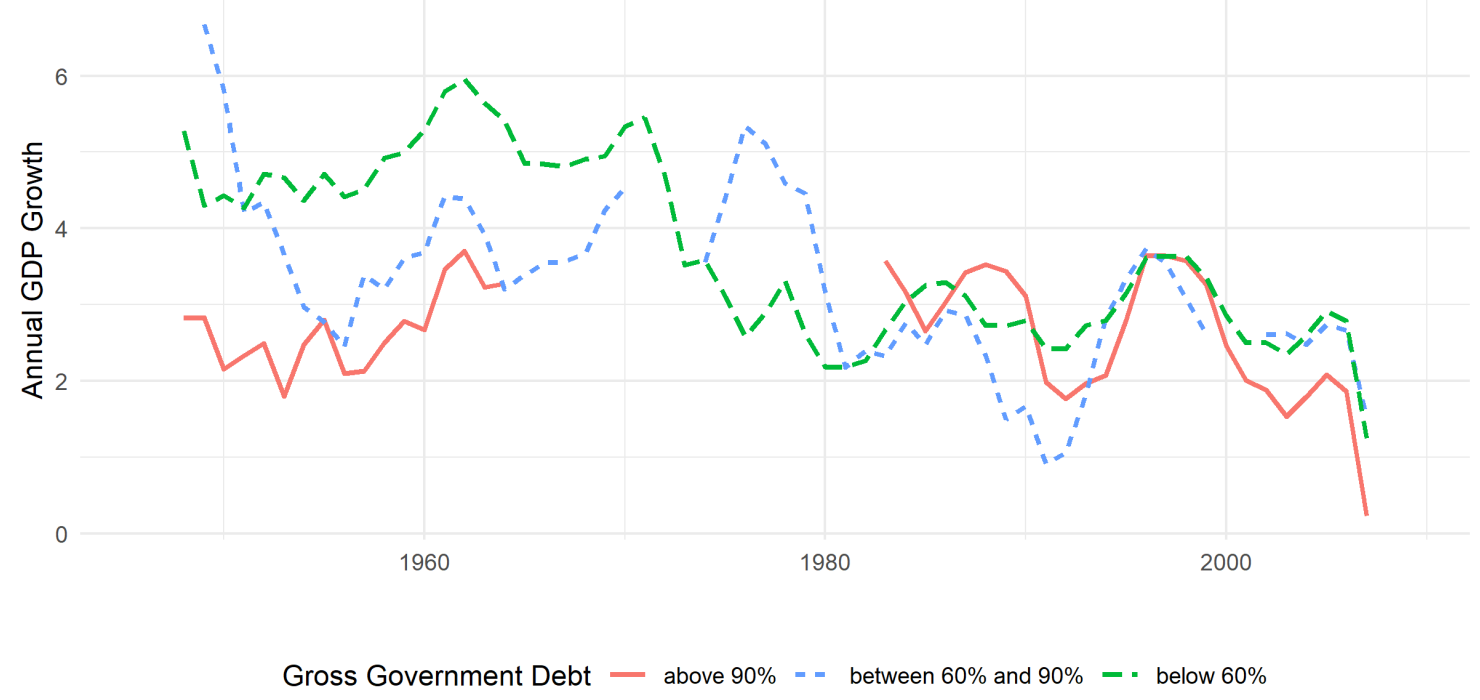

(a) Smoothed median GDP growth rates over time

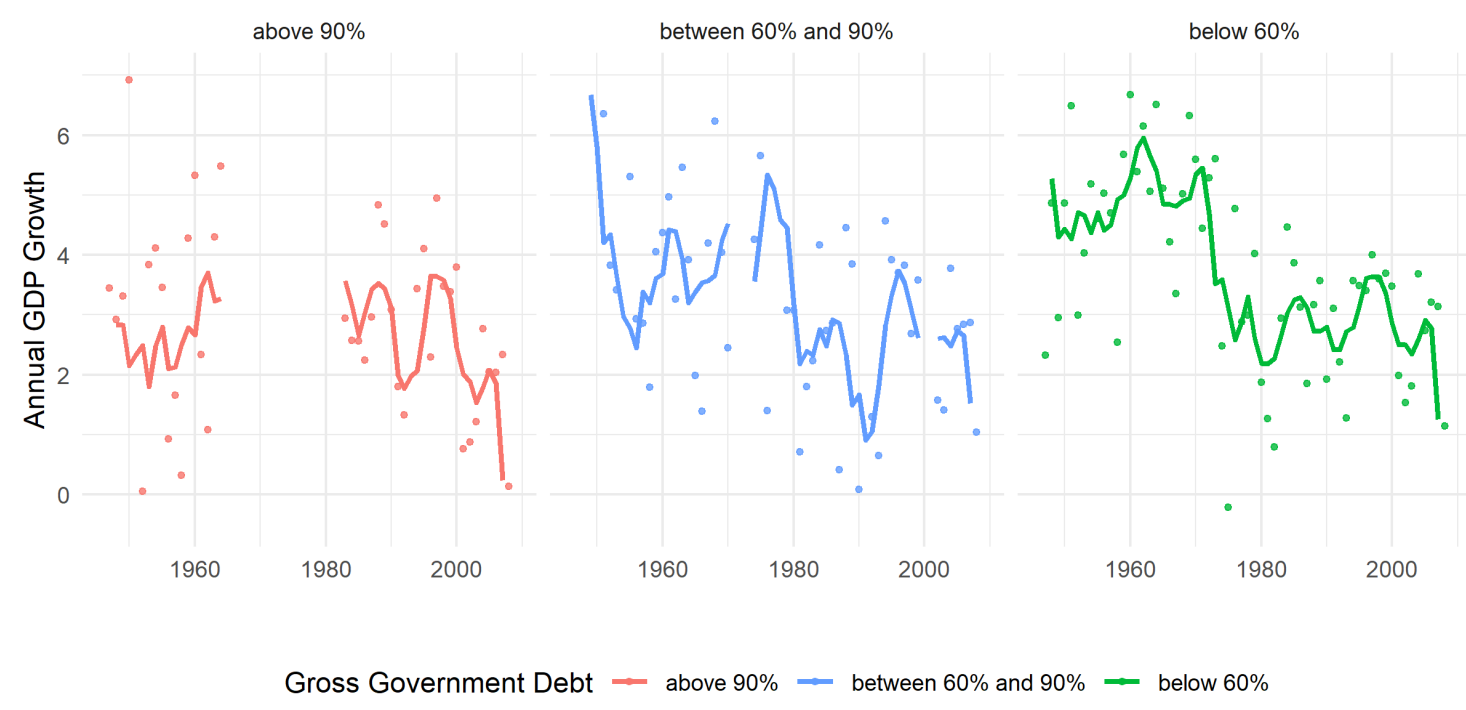

(b) Smoothed median GDP growth rates and scatters per debt regimes over time

In our efforts to analyse the inter-temporal relation between economic growth and public debt, we plot the median annual, one period ahead, GDP growth rates for each country of the Reinhart and Rogoff (2010) data set over time. In order to reduce the noise of the series we replace the actual series with their respective third order moving average representation and associate each regime with the corresponding high, medium and low 
debt regimes of above $90 \%$, between $60 \%$ and $90 \%$ and below $60 \%$ using the colours red, blue and green respectively. We present a disaggregated, individual-country-type version of this graph in Figure D.7 for further reference.

The findings in Reinhart and Rogoff (2010) imply that countries with higher public debt levels are associated with much lower growth rates. Thus, with the data presented in this way we would expect to see a 'sandwich-like' pattern in Figure 1a where the red line would be present at lower GDP growth rates, followed by blue and eventually green both of which associated with more favourable debt regimes. Instead we observe that gross government debt levels in excess to $90 \%$ are more apparent at the beginning and the very end of the sample. Between 1960 and 1980 most countries are associated with the low debt regime. Additionally, we see that the general pattern of GDP growth rates is downwardssloping and seems to be less volatile across the sample of countries since the $1980 \mathrm{~s}$.

For the period starting in 1980, there seems very little difference in the growth performances of countries across all three regimes. Furthermore, we can see the devastating effect of the financial crisis on GDP growth rates at the very end of the sample represented by a universal and steep drop across all observed countries. Figure $1 \mathrm{~b}$ allows for some additional insights with regards to the volatility of economic growth across the three regimes, illustrated by adding the actual median growth rates for each year and three debt regimes respectively. This helps to illustrate the strong pattern of variability across all regimes, with no distinct regime-specific patterns.

Equipped with these insights we next apply the same visual tools on the quarterly OECD data. We do this as we are interested to see if the previously observed patterns also hold true for the more recent past, as well as on a higher-frequency level and, in particular, how the financial crisis and the post-crisis era have left their marks on the data. As before we present a disaggregated, individual-country-type version of this graph in Figure D.9 for further reference. Interestingly, in Figure $2 \mathrm{a}$ we again fail to recognise the previously hypothesised sandwich-like layering of growth rates but find that most countries recorded moderate growth rates and appear to move together. What is striking, is how similar the evolution of the median growth rates across all three debt regimes plays out. This joint trend also continued during the crisis: Independent of the level of debt, all countries were similarly struck by this seismic economic event with very little volatility in the variation of growth rates across debt regimes (Figure 2b). There also seems to be little visual evidence to suggest that the absorption of the financial crisis reflected by the decline in the growth rates seem to be associated with the debt regime of the corresponding countries in any way: As a matter of fact, we observe the highest drops in GDP growth rates during the financial crisis for two countries associated with the low debt regime, Finland and Ireland, a slump which was only surpassed by Greece in 2011.

We see this as clear empirical evidence against the idea that countries with higher debt levels have been struck more severely by the crisis or have experienced a more sluggish recovery after the crisis. Quite to the contrary, it seems suggestive of the fact that the crisis has had a 'unifying' effect on the growth dynamics across regimes. Whilst the 
above analysis provides some important insight into the relationship of economic growth and public debt over the last decades and through the financial crisis in particular, it does not provide sufficient evidence to make a statement with regards to the inter-temporal direction of causality on a more general level.

Figure 2: GDP Growth, quarterly OECD data, 1996Q01 to 2018Q2

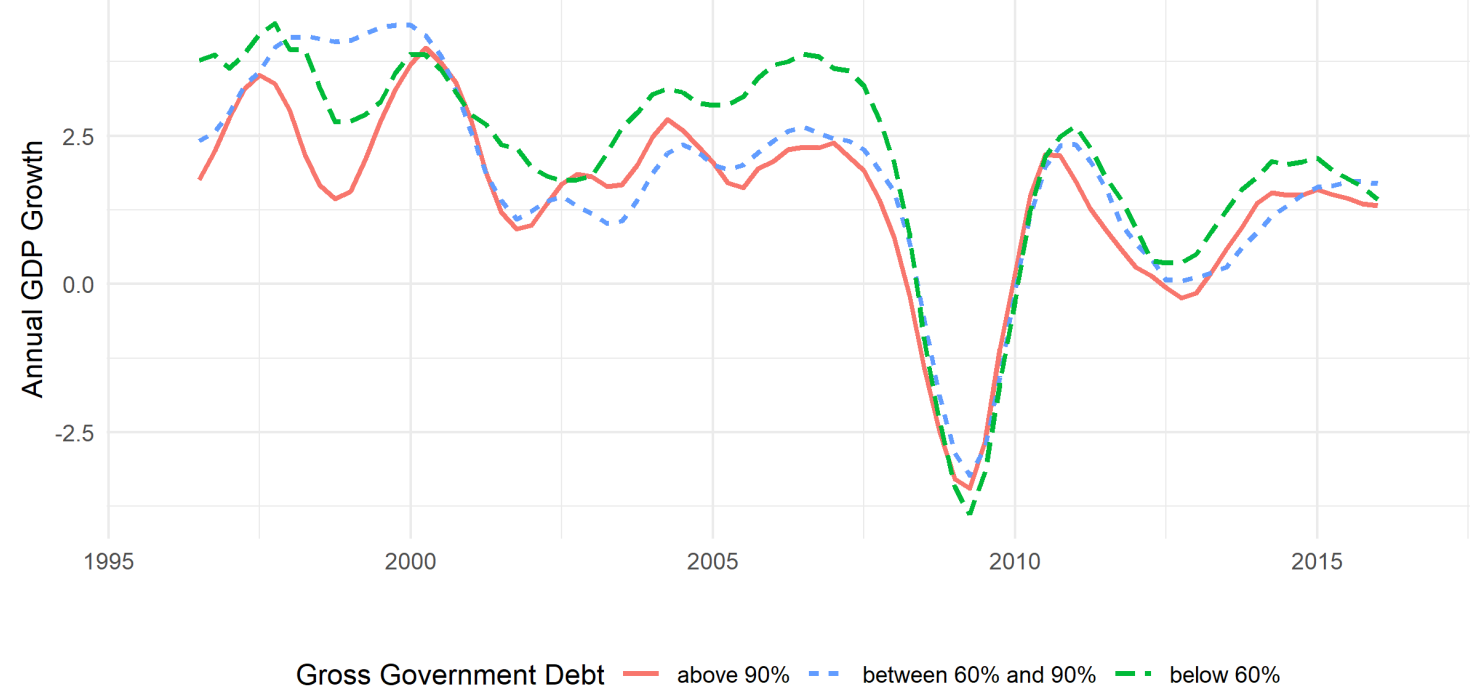

(a) Smoothed median GDP growth rates over time

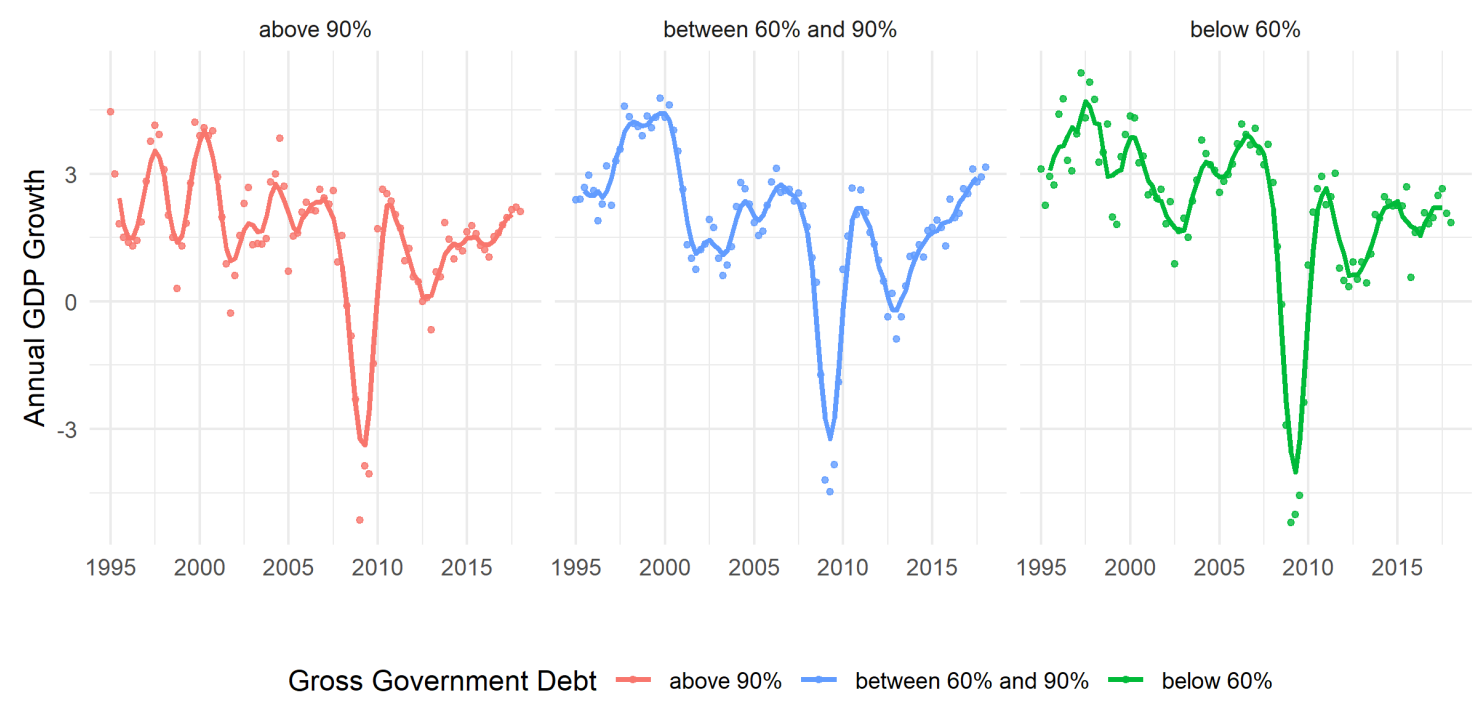

(b) Smoothed median GDP growth rates and scatters per debt regimes over time

We try to address this issue in Figure 3 where we again use Reinhart and Rogoff (2010)'s annual data set and plot the levels of the debt-to-GDP ratio against time. As we are particularly interested in learning about the timing of the changes in the debt structures that are associated with the lower growth regimes, we fade out the high growth regime of above $2 \%$ by only depicting it in a light grey. ${ }^{4}$ Our rational behind this is the following: If 
high public debt is causing low economic growth, we would assume to see more medium and low growth regimes associated with countries with higher debt levels. Furthermore, if the negative link from high debt to low growth holds universally true, we would expect their growth regime to change from grey to blue for lower levels of debt and consequently to red at (or around) the debt overhang regime of $90 \%$.

Figure 3: Debt-to-GDP ratio, Reinhart and Rogoff (2010) data, 1946 to 2009

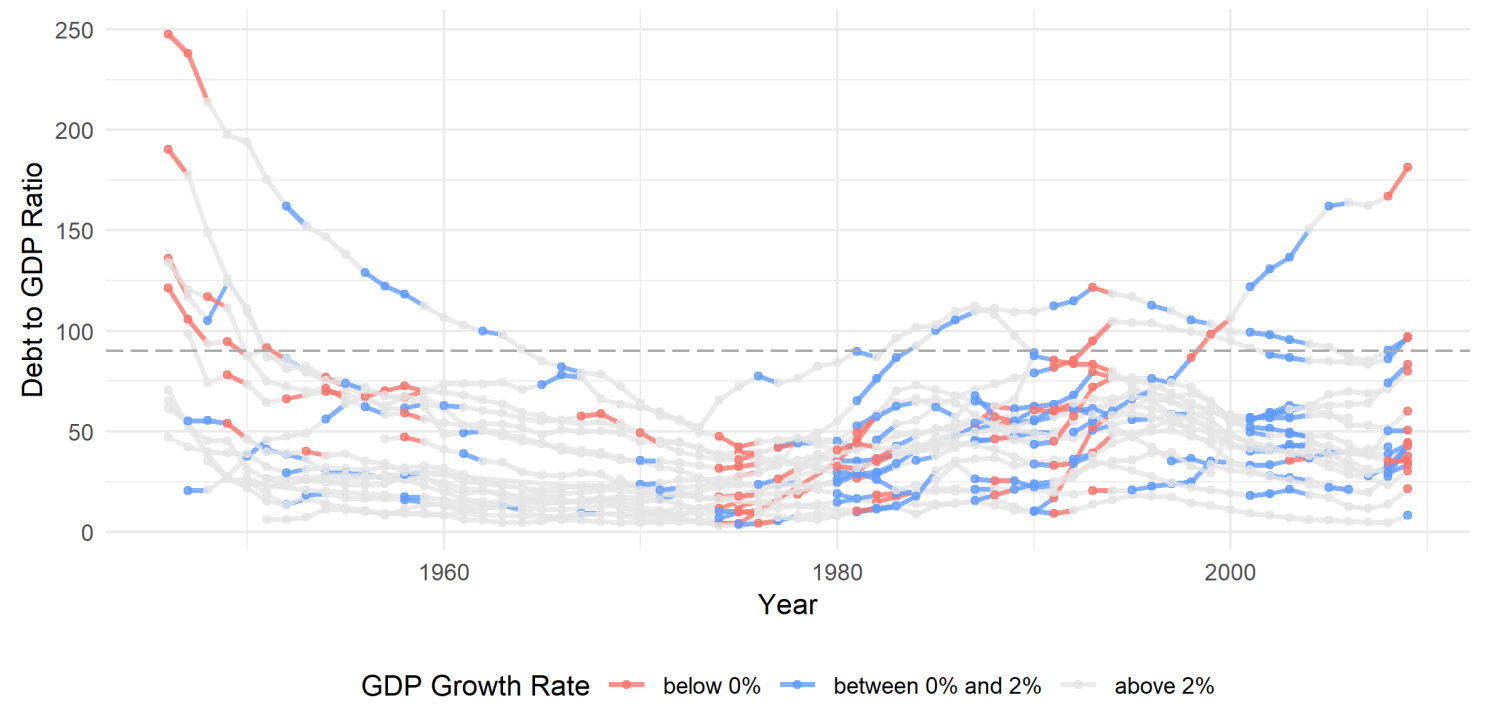

However, the empirical evidence presented in Figure 3 draws a different picture: Rather than being typically present for extremely high levels of the sovereign debt ratio, periods of low economic growth seem to occur at similar time periods across countries (and have become more frequent in the 1980s to mid-1990s). In other words, visual evidence is more suggestive of economic growth being affected by exogenous factors 'other' than the actual level of the debt-to-GDP ratio at the time of the crisis. Further inspection of the graphs also shows that periods of low economic growth are typically followed by build-ups in public debt which can be seen when noting that almost all more accentuated line segments, which are associated with lower growth regimes, are upwardsloping. This pattern is particularly pronounced in the 1980 s, suggesting instead a reverse causality link of economic growth on public debt.

What is more, it is our opinion that Figure 3 provides a strong counterargument against the 'debt-threshold' hypothesis represented by the vertical, dashed line at $90 \%$ of the debt-to-GDP ratio. Given the evolution of debt levels over time and their corresponding growth regimes, this figure leaves little to no room for the credible argument that, at least for this sample of countries, there could be a tipping point at 90 percent which would demolish economic growth. Finally, we again turn to the quarterly OECD data in Figure 4. We observe that the debt levels before the financial crisis were rather stable and the majority of countries were reporting growth rates of two or more percent. Similar to previous observations. With regards to the timing of movements, the financial crisis led to a big drop in economic activity resulting in a negative growth rate for almost all countries in the sample, followed by a considerable increase in sovereign debt levels. 
These results, together with the historical evidence on how Western economies reacted to the unfolding of the financial crisis, throws doubt on any hypothesis suggesting the debt build-ups were caused by anything else but the financial crisis. Furthermore, even though debt levels came to a rise for almost all countries in the sample, GDP growth rates turned positive around the beginning of 2010 which can be verified in Figure D.10. For example, Italy, with a very high debt ratio before the financial crisis, also had growth rates return to normal in 2010. After a second setback in late 2011, GDP growth finally returned to levels between zero and 2 percent in 2013 - at a debt ratio of 130 percent. Similar trends of non-negative growth regimes far above the 90 percent debt threshold can be observed in a wide range of countries including France, Spain, the United Kingdom or the US.

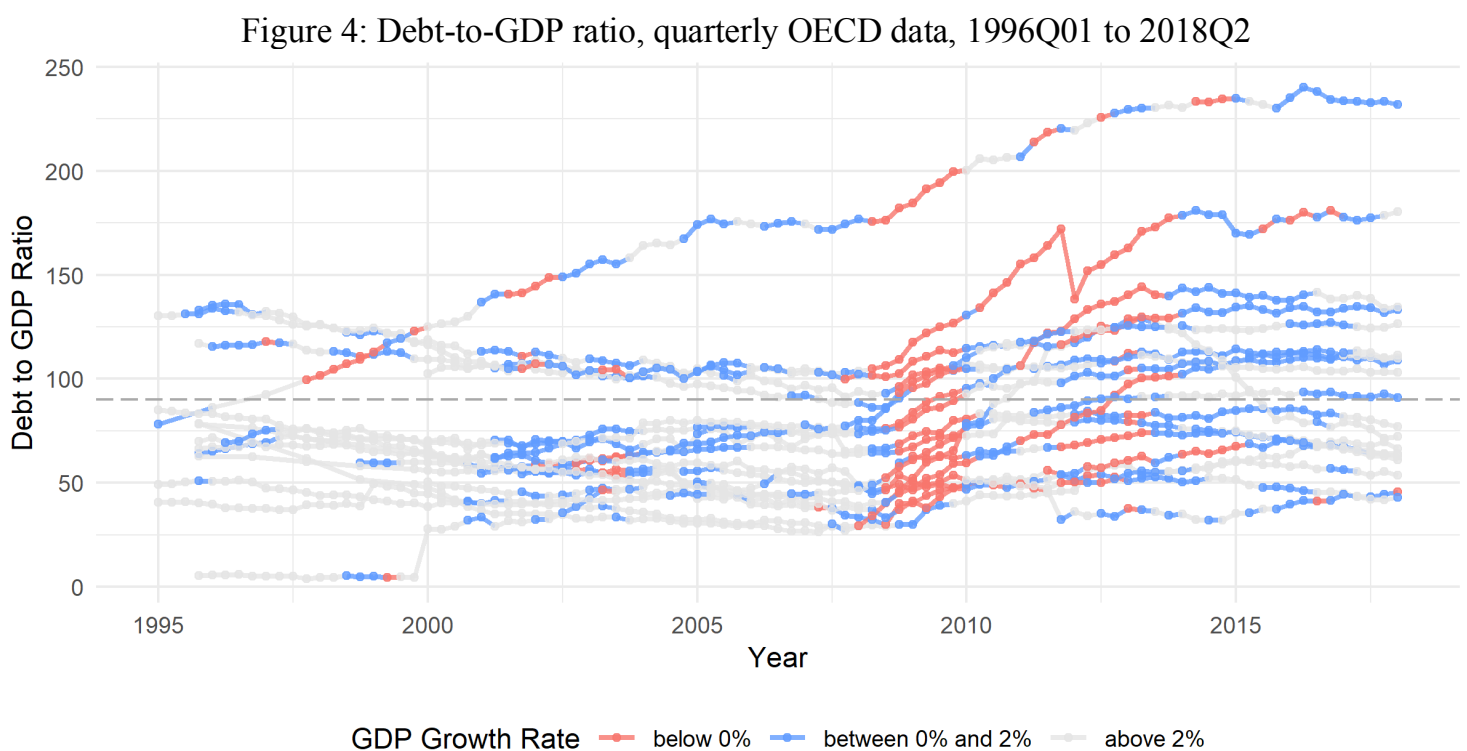

We summarise with the following points: By means of a straightforward inspection of two separate data sets we present evidence that low growth periods happen much around the same time for our sample of countries, suggesting that common external economic shocks might at least be partially responsible for this pattern. Furthermore, the plots suggest that the actual levels of the debt-to-GDP ratio are very unlikely to be associated with a particular growth regime. A key insight of this analysis is that if, as argued by Reinhart and Rogoff (2010), high public debt is detrimental to economic growth, high debt levels should generally be associated with more and longer spells of low growth rates. Instead, what we see is that growth slumps generally appear to happen before an increase in the debt level; but it does not seem to depend on the initial level of the debt share. Consequently, it is our opinion that the notion of a significant and homogeneous debt threshold at $90 \%$ is lacking any factual or empirical foundation.

\subsection{Non-linearities and Thresholds}

We acknowledge the argument that even if previous debt levels might not have been detrimental in causing low economic growth, as suggested in our analysis, this does not 
mean that sovereign debt induced economic slowdowns are an impossibility. In other words, even though our analysis has shed some light on the question of potential causality linkages and highlights the role of global economic factors and dynamics, we cannot argue or conclude by any means that there might not be a debt threshold level at which economic growth is impeded. Even if this threshold may not be at $90 \%$ for the annual data set, we might very well find a threshold effect at other levels. Conversely, as far as the more recent, quarterly data is concerned, a significant number of countries have reported ever increasing debt levels as a result of the financial crisis.

From the empirical tools used so far it is unclear as to how these countries experienced growth rates significantly lower than their counterparts, below the 90 percent cut-off. With this issue in mind we analyse the evolution of average, short- to long-run growth rates for various debt levels. In doing so we explicitly consider the growth performances of countries which either surpass a particular debt threshold level $\tau$ from below and remain above said threshold for the consecutive period, as well as countries that report debt levels above $\tau$ in both periods. We do this because we are interested in the distribution of contemporary as well as mid-run growth performances conditioned on varying debt threshold levels.

In more mathematical terms, we define the $k$-period-ahead average growth rate for each debt threshold level $\tau$ as

$$
\bar{g}_{k, \tau}=\frac{1}{T_{\tau}} \frac{1}{N_{\tau}}\left(\sum_{i=1}^{N_{\tau}} \sum_{t=1}^{T_{\tau}} g_{k, i, t} \times \mathbf{1}\left(D_{i, t}, \tau\right)\right)
$$

where the $k$-period-ahead average growth rate for an arbitrary country $i$ and time period $t$ is calculated as

$$
g_{k, i, t}=\left(\left(\frac{G D P_{i, t+k}}{G D P_{i, t}}\right)^{(m / k)}-1\right)
$$

for annual $(m=1)$ and quarterly $(m=4)$ data respectively and

$$
1\left(D_{i, t}, \tau\right)= \begin{cases}1 & \text { if } D_{i, t} \geq \tau \wedge\left(D_{i, t-1} \leq \tau \vee D_{i, t-1} \geq \tau\right), \\ 0 & \text { otherwise }\end{cases}
$$

Furthermore, we define

$$
T_{\tau}=\sum_{t=1}^{T_{\tau}} 1\left(D_{i, t}, \tau\right)
$$

and equivalently for $N_{\tau}{ }^{5} \mathrm{We}$ assess the relationship between GDP growth and potential debt thresholds by calculating $\bar{g}_{k, \tau}$ for $\tau=\{20,25, \ldots, 155,160\}$ and $k=\{1,5,10,15\}$ for the annual as well as $k=\{4,10,40\}$ for the quarterly data set. This allows us to compare the one-, five- and ten-year-ahead GDP growth rates from both data sets of our interest. We present the results in Figure 5 and Figure 6 where we plot the average growth rates ${ }^{-} g_{k, \tau}$ 
and the corresponding $5^{\text {th }}$ and $95^{\text {th }}$ percentile against the possible levels of $\tau$ using the annual as well as quarterly data sets respectively.

Figure 5: Average $k$-period-ahead GDP growth rates vs. debt threshold levels $\tau$, Reinhart and Rogoff (2010) data, 1946 to 2009

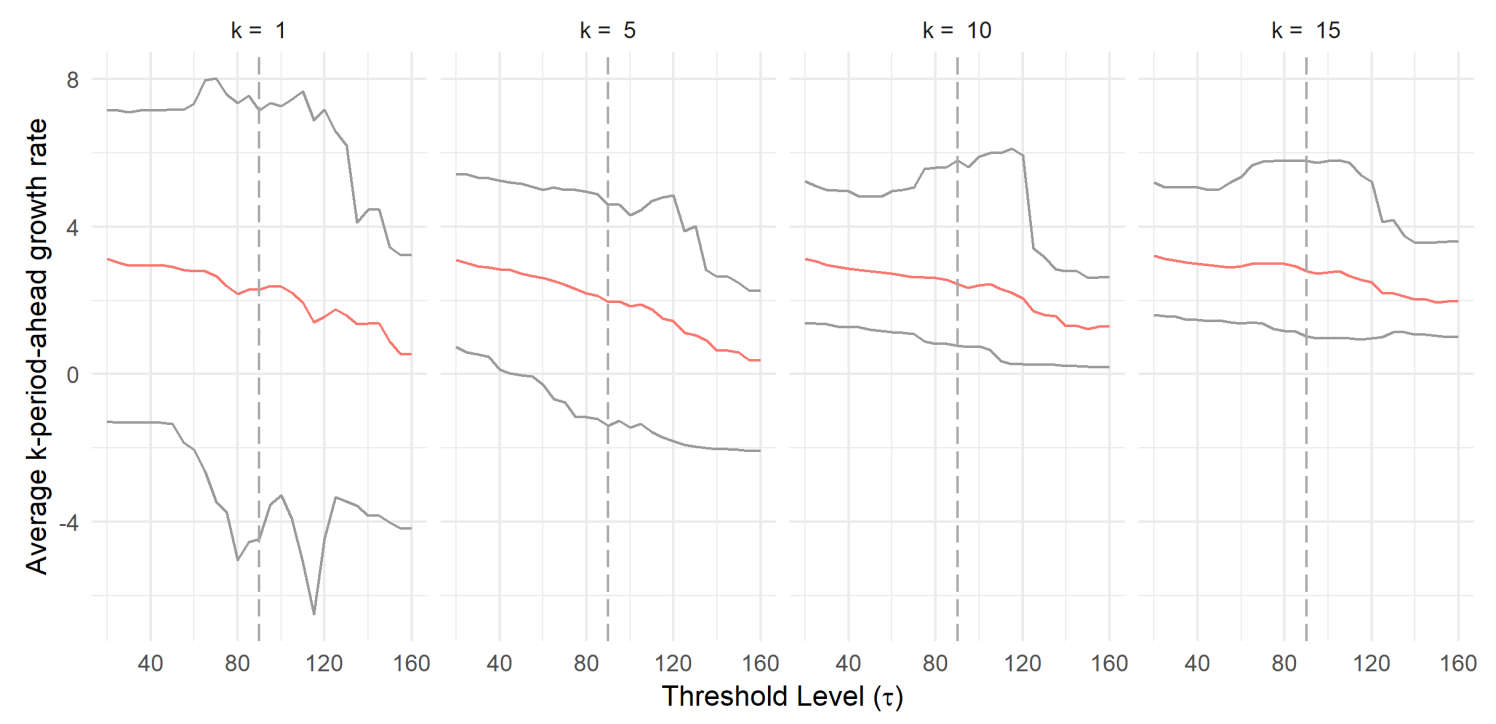

Generally speaking, our results are in line with comparable approaches undertaken in the literature; see e.g. Pescatori et al. (2014). More precisely, in Figure 5, we observe that for the annual data, the one-period-ahead growth rate presented in the outer-left panel can be associated with a relatively strong negative trend for GDP growth rates. Similar to other exploratory pieces exploiting the corrected Reinhart and Rogoff (2010) data base, we observe that one-period-ahead GDP growth rates at a threshold level of $\tau=90$ (illustrated by a dashed vertical line) are associated with a mean GDP growth rate of somewhat above 2 percent. We also observe a very high degree of heterogeneity: The grey, vertical lines associated with each plot show the variation of the $5^{\text {th }}$ to $95^{\text {th }}$ percentile of the data. Observing the evolution of average growth rates over increasing values of $\tau$ in the outer left panel, we also note that there seems to be little to no evidence of a debt threshold compatible with the $90 \%$ hypothesis. However, we do observe a notable yet steady drop in average one-period-ahead growth rates for a debt level of 20 percent (of somewhat above 3 percent) versus a debt level of 160 percent (.5 percent).

As noted earlier, one should be cautious when deducing a causal relationship of high debt adversely affecting GDP growth because of (possible) endogeneity feedback mechanisms. Consequently, and similar to the empirical literature discussed in the first part of this piece, we try to mitigate this problem by extending the time horizon of the analysis which also lets us smooth out business-cycle effects as well as outliers to analyse the five, ten- as well as 15-year-ahead GDP growth rate in panels two to four in Figure 5. Comparing these findings with the simple one-period-ahead growth rates, three observations seem particularly noteworthy: First of all, when increasing the time period considered, we see noticeably less variation in the data. This seems to go hand-in-hand 
with a less pronounced reduction of average GDP growth rates with increasing levels of $\tau$, that is, the observed reduction in average growth rates associated with increased sovereign debt ratios decreases over the mid-term.

Most interestingly, this rotation of the average growth rate line seems to be the result of fewer observations with high, negative growth rates. This result is intuitive and is in line with our previous observations: Crises can typically be characterised by a sharp drop in average growth rates and seem to generally lead to a debt build-up afterwards. However, when considering longer time periods, these dramatic events are typically smoothed out and hence the hypothesised causal relationship from debt to growth would be expected to wash out too. This is precisely what we observe in Figure 5 when comparing, in particular, the $5^{\text {th }}$ percentile across all four panels: Most notably, for the case of $k=15$, we see that 95 percent of all recorded cases show an average growth rate of approximately 1.5 percent for a debt level of $\tau=20$ compared to approximately 1 percent for $\tau=160$.

Figure 6: Average $k$-period-ahead GDP Growth rates vs. debt threshold levels $\tau$, quarterly OECD data, 1996Q01 to 2018Q2

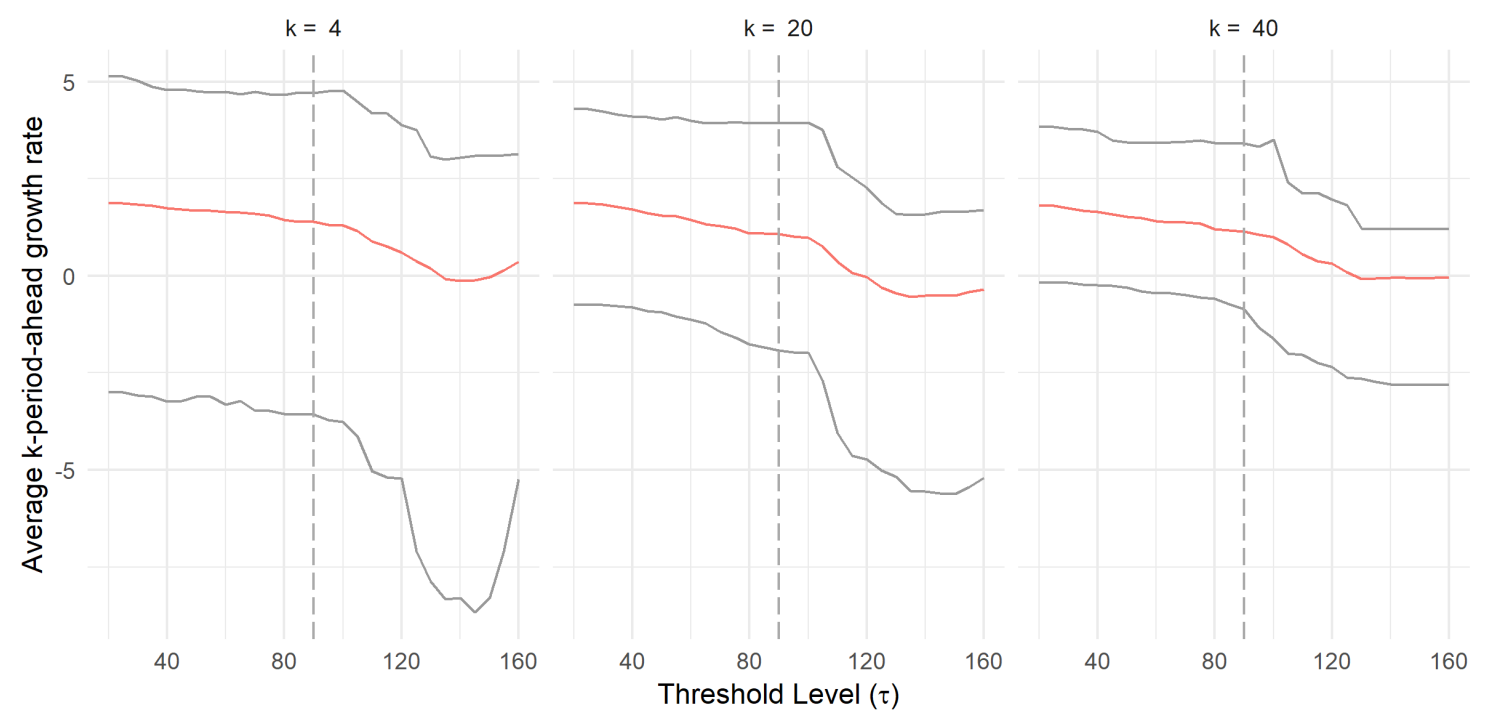

Finally, we apply the same approach to our quarterly data set from the OECD. For this case, and because of data availability issues, we limit our analysis to the one-, fiveand ten-year-ahead growth rates only. From Figure 6, we can see some consistency with our results using the corrected Reinhart Rogoff (2010) data set: extending the time horizon smooths out negative effects and reduces variation, also that mid-run growth rates seem to be consistently above the 1 percent mark for 95 percent of the considered sample and debt levels up to $\tau=160$. In contrast to our earlier results, we can see more clearly the increased uncertainty around $\mathrm{k}$ period ahead growth rates caused by the quarterly fluctuations and the increase in volatility in growth rates from 2009 onwards. Nevertheless, growth figures are nowhere near the negative aggregates reported in Reinhart and Rogoff (2010) for the $90 \%$ threshold, of which there appears to be very little evidence. 


\section{Conclusion}

The continuing debate over the imposition of measures to deal with sovereign indebtedness, since the financial crisis, has become centred on the seminal contribution by Reinhart and Rogoff (2010). With the wide adoption of fiscal discipline policies, also known as austerity, the importance of this perspective for economic policy should not be overstated. Since the publication of various inaccuracies in methodology pointed out by Herndon et al. (2014) amongst others, the argument has continued unabated. Our straightforward contribution to this topic critically assesses the results in Reinhart and Rogoff (2010) and the empirical strands of literature that have evolved from the 'debtthreshold' view.

The discussion of the empirical literature reveals that there is mixed to little evidence of any negative causal effect of high sovereign debt upon economic growth and that cross-country heterogeneity seems to play a crucial role in the analysis of the relationship. In the second part of our study we have offered a time series perspective by contrasting the widely used Reinhart and Rogoff (2010) data with a second more recent and higher frequency OECD data source. Using the second data source allows a robustness exercise in our analysis and offers a more sophisticated view of the direction of this contentious relationship. Furthermore we enjoy a sample that encompasses a full decade after the financial crisis and one that controls for changes in the dynamics between public debt and economic growth since.

When analysing the inter-temporal linkage between growth and debt, our time series analysis provides crucial evidence on the much debated possibility that growth can be endogenous on the level of external public debt. Whereas some previous studies have assumed that this causality is one way, our study of the data lends itself to the 'reverse' causality hypothesis. We build this argument, firstly, on the observations that the times series plots for growth in GDP, over the last six decades, reveal a downward trend over the sample; a fact which could be the actual explanation for any negative correlation between debt and growth. Secondly, after the financial crisis, it is evident that the number of higher debt regimes has exploded; offering support for reverse causality of debt caused by economic slumps. Thirdly, it seems that periods of low growth tend to be clustered around common time periods for many countries and not bound to country samples displaying particularly high levels of debt, thereby offering further support for reverse causality.

In addressing the question of the existence of a debt threshold, we find no evidence that countries will experience significant reductions in GDP growth after surpassing a certain percentage of the debt-to-GDP ratio. We draw this conclusion from observing the evolution of average growth rates (and their variation) over an interval of very low to very high aggregate debt levels. We demonstrate that the average negative relationship between economic growth and the debt-to-GDP ratio strongly depends on the time dimension of consideration, and that accounting for business-cycle effects and short-term volatility accounts for much of the negative variation in growth figures. Our observations add to the evidence for the case of 'reverse causality' and suggest that a much more rigorous analysis on the effects of higher public debt is required, especially where the policy impact of a study is so high. 


\section{References}

Abbas, S. A., Belhocine, N., Elganainy, A., Horton, M., 2010. A Historical Public Debt Database. IMF Working Paper (WP/10/245), 1-26.

Afonso, A., Hauptmeier, S., apr 2009. Public Debt and Economic Growth: a Granger Causality Panel Data Approach. Working Papers Department of Economics 2009/24, ISEG - School of Economics and Management, Department of Economics, University of Lisbon.

URL https://ideas.repec.org/p/ise/isegwp/wp242009.html

Afonso, A., Jalles, J. T., 2013. Growth and productivity: The role of government debt. International Review of Economics \& Finance 25, 384-407.

URL http://www.sciencedirect.com/science/article/pii/S1059056012000640

Amann, J. and Middleditch, P., 2017. Growth in a time of austerity: Evidence from the UK. Scottish Journal of Political Economy, 64: 349-375.

Baek, E., Brock, A., 1992. A General Test for Non-Linear Granger Causality: Bivariate Model. URL http://www.ssc.wisc.edu/\{ \}wbrock/BaekBrockGranger.pdf

Balassone, F., Francese, M., Pace, A., 2011. Public Debt and Economic Growth in Italy. Quaderni di Storia Economica (11).

Barro, R. J., Ursula, J. F., 2010. Barro-Ursua Macroeconomic Dat. URL http://scholar.harvard.edu/barro/publications/barro-ursua-macroeconomic-data

Baum, A., Checherita-Westphal, C., Rother, P., 2013. Debt and growth: New evidence for the euro area. Journal of International Money and Finance 32 (1), 809-821.

Bazzi, S., Clemens, M. A., apr 2013. Blunt Instruments: Avoiding Common Pitfalls in Identifying the Causes of Economic Growth. American Economic Journal: Macroeconomics 5 (2), 152-186.

URL https://ideas.repec.org/a/aea/aejmac/v5y2013i2p152-86.html

Bell, A., Johnston, R., Jones, K., 2015. Stylised fact or situated messiness? The diverse effects of increasing debt on national economic growth. Journal of Economic Geography 15 (2), 449-472.

Bohn, H., 2008. The sustainability of fiscal policy in the United States. In: Neck, R., Sturm, J.-E. (Eds.), Sustainability of public debt. Cambridge, Ch. 2, pp. 15-50.

Bolt, J., van Zanden, J. L., 2014. The Maddison Project: Collaborative research on historical national accounts. Economic History Review 67 (3), 627-651.

Bond, S., apr 2002. Dynamic panel data models: a guide to microdata methods and practice. CeMMAP working papers CWP09/02, Centre for Microdata Methods and Practice, Institute for Fiscal Studies.

URL https://ideas.repec.org/p/ifs/cemmap/09-02.html

Bun, M. J. G., Windmeijer, F., mar 2007. The Weak Instrument Problem of the System GMM Estimator in Dynamic Panel Data Models. Bristol Economics Discussion Papers 07/595, Department of Economics, University of Bristol, UK.

URL https://ideas.repec.org/p/bri/uobdis/07-595.html

Caner, M., Grennes, T. J., K"ohler-Geib, F. F. N., 2010. Finding the Tipping Point - When Sovereign Debt Turns Bad. SSRN Electronic Journal (Pozen), 1-15.

URL papers2://publication/livfe/id/86777\{\%\}5Cnhttp://www.ssrn.com/abstract= 1612407\{\%\}5Cnhttp://www.ssrn.com/abstract=1612407

Casni, A. C., Badurina, A. A., Sertic, M. B., 2014. Public debt and growth: evidence from Central, Eastern and Southeastern European countries. Zbornik radova Ekonomskog fakulteta u Rijeci/Proceedings of Rijeka Faculty of Economics 32 (1), 35-51.

URL http://ideas.repec.org/a/rfe/zbefri/v32y2014i1p35-51.html

Cecchetti, S. G., Mohanty, M. S., Zampolli, F., 2011. Achieving Growth Amid Fiscal Imbalances: The Real Effects of Debt. Economic Symposium Conference Proceedings 352 (August), 145-96.

URL http://www.bis.org/publ/work352.htm

Chang, T., Chiang, G., June 2012. Transitional Behavior of Government Debt Ratio on Growth: The Case of OECD Countries. Journal for Economic Forecasting 0 (2), 24-37.

URL https://ideas.repec.org/a/rjr/romjef/vy2012i2p24-37.html

Checherita-Westphal, C., Rother, P., 2012. The impact of high government debt on economic growth and its channels: An empirical investigation for the euro area. European Economic Review 56 (7), 1392-1405. 
Christopoulos, D. K., Le'on-Ledesma, M. A., 2008. Testing for Granger ( Non- ) causality in a Time-Varying Coeffi cient. Journal of Forecasting (27), 293-303.

Chudik, A., Mohaddes, K., Pesaran, M. H., Raissi, M., 2015. Is There a Debt-threshold Effect on Output Growth? IMF Working Papers 15/197.

Domar, E. D., 1944. The external Debt Burden and National Income.

Dube, A., 2013. A Note on Debt, Growth and Causality.

URL https://dl.dropboxusercontent.com/u/15038936/RRTimepath/Dube_Growth_Debt_ Causation.pdf

Eberhardt, M., Presbitero, A. F., 2015. Public debt and growth: Heterogeneity and non-linearity. Journal of International Economics 97 (1), 45-58.

URL http://www.sciencedirect.com/science/article/pii/S0022199615000690

Egert, B., 2012. Public Debt , Economic Growth and Nonlinear Effects: Myth or Reality. OECD Economics' Department Working Papers (993).

Egert, B., 2013. The 90\% Public Debt Threshold: The Rise and Fall of a Stylised Fact. OECD Economics' Department Working Papers 1055, 1-31.

Furceri, D., Zdzienicka, A., 2012. How costly are debt crises? Journal of International Money and Finance 31 (4), 726-742.

Galvão, A. B. C., 2006. Structural break threshold VARs for predicting us recessions using the spread. Journal of Applied Econometrics 21 (4), 463-487.

G'omez-Puig, M., Sosvilla-Rivero, S., 2015. The causal relationship between debt and growth in EMU countries. Journal of Policy Modeling 37 (6), 974-989.

Haque, N. U., Pesaran, M. H., Sharma, S., jan 1999. Neglected Heterogeneity and Dynamics in Cross-country Savings Regressions. Cambridge Working Papers in Economics 9904, Faculty of Economics, University of Cambridge.

URL https://ideas.repec.org/p/cam/camdae/9904.html

Herndon, T., Ash, M., Pollin, R., 2014. Does high public debt consistently stifle economic growth? A critique of Reinhart and Rogoff. Cambridge Journal of Economics 38 (2), 257-279.

Hsiao, C., 1981. Autoregressive modelling and money-income causality detection. Journal of Monetary Economics 7 (1), 85-106.

Irons, J., Bivens, J., 2010. Government Debt and Economic Growth Overreaching Claims of Debt Threshold Suffer from Theoretical and Empirical Flaws. Economic Policy institute 271, 1-9.

K'onya, L., 2006. Exports and growth: Granger causality analysis on OECD countries with a panel data approach. Economic Modelling 23 (6), 978-992.

Konzelmann, S. J., 2014. The political economics of austerity. Cambridge Journal of Economics 38 (4), 701741.

Kourtellos, A., Stengos, T., Tan, C. M., 2013. The effect of public debt on growth in multiple regimes. Journal of Macroeconomics 38 (PA), 35-43.

URL https://ideas.repec.org/a/eee/jmacro/v38y2013ipap35-43.html

Lof, M., Malinen, T., 2014. Does sovereign debt weaken economic growth? A panel VAR analysis. Economics Letters 122 (3), 403-407.

Lütkepohl, H., 1982. Non-causality due to omitted variables. Journal of Econometrics 19 (2-3), 367-378.

Minea, A., Parent, A., 2012. Is High Public Debt Always Harmful to Economic Growth? Reinhart and Rogoff and some complex nonlinearities. Working Papers 201218, CERDI.

URL http://ideas.repec.org/p/cdi/wpaper/1355.html

Neck, R., Sturm, J.-E., 2008. Introduction and overview. In: Neck, R., Sturm, J.-E. (Eds.), Sustainability of public debt. Cambridge, Ch. 1, pp. 1-14.

Padoan, P. C., Sila, U., van den Noord, P., jun 2012. Avoiding Debt Traps: Financial Backstops and Structural Reforms. OECD Economics Department Working Papers 976, OECD Publishing.

URL https://ideas.repec.org/p/oec/ecoaaa/976-en.html

Panizza, U., Presbitero, A. F., 2014a. Public debt and economic growth: Is there a causal effect? Journal of Macroeconomics 41, $21-41$.

URL http://www.sciencedirect.com/science/article/pii/S0164070414000536

Panizza, U., Presbitero, A. F., 2014b. Public debt and economic growth: Is there a causal effect? Journal of Macroeconomics 41, 21-41. 
Pescatori, A., Sandri, D., Simon, J., 2014. Debt and Growth: Is There a Magic Threshold?

URL http://elibrary.imf.org/view/IMF001/21178-9781484306444/21178-9781484306444/21178-

9781484306444.xml

Puente-Ajovín, M., Sanso-Navarro, M., 2015. Granger causality between debt and growth: Evidence from OECD countries. International Review of Economics \& Finance 35 (C), 66-77.

URL https://ideas.repec.org/a/eee/reveco/v35y2015icp66-77.html

Reinhart, C. M., Reinhart, V. R., Rogoff, K. S., 2012. Public Debt Overhangs: Advanced-Economy Episodes since 1800. Journal of Economic Perspectives 26 (3), 69-86.

Reinhart, C. M., Rogoff, K. S., 2010. Growth in a time of debt. American Economic Review 100 (2), $573-$ 578. Woo, J., Kumar, M. S., 2015. Public Debt and Growth. Economica 82 (328), 705-739. 


\section{Appendix A. Notes}

1. It has to be noted that the debt regime classifications follow the ad hoc rule outlined in the paper based on two secondary data sets and may at times be inconsistent across sets or provide data for non-overlapping periods only; see e.g. Italy or Greece in Figure D.7 vs. Figure D.9. It is noteworthy to point out that the results of the analysis hold despite these inconsistencies. Whereas there is some considerable variation with regards to the variables analysed in this study across both data sets, Table B.1 reveals that both sets are internally consistent over their domains.

2. See for example Olli Rehn, EU Commissioner for Economic Affairs, at International Labor Organisation on 9th April 2013 (http://europa.eu/rapid/press-release SPEECH-13-294_en.htm?locale=en), Paul Ryan, Chairman House Budget Committee, in 'The Path to Prosperity. A Blueprint for American Renewal' (http://budget. house.gov/uploadedfiles/pathtoprosperity2013.pdf) or, as noted by Minea and Parent (2012), the OECD, the EU Commission and the French Report on Public Finance in 2010.

3. Exemplarily, multiple studies have been concerned with the sustainability of debt policies which, among other techniques, base their assumption of debt sustainability on time-series properties of the debt variable; see e.g. Neck and Sturm (2008) or Bohn (2008) for a comprehensive survey of this field.

4. We keep the previously defined colours for the medium and low regimes. For the country-level figures in the appendix we resort to the previously defined red, blue and green colour pattern for both the Reinhart and Rogoff (2010) data in Figure D.8 as well as the quarterly OECD data in Figure D.10.

5. It would be interesting to compare the debt-trajectories of countries surpassing the debt threshold from below with the average growth rate and its deviation for the group of countries that surpass the same debt threshold from above or to introduce an additional requirement, that any country would have to stay above (below) the various threshold values for a pre-specified time period to eliminate short-term disturbances. As it stands, this is left for further research.

\section{Appendix B. Data}

For annual data, we use the corrected Reinhart and Rogoff (2010) data set by Herndon et al. (2014, publicly accessible at https://www.peri.umass.edu/publication/item/526does-high-public-debtconsistently-stifle-economic-growth-a-critique-of-reinhartand-rogo-ff, last visit February 2017) and follow the authors' sampling choices to obtain 1-period-ahead GDP growth rates for a sample of 20 OECD countries for the period 1946 to 2009 . We composed our quarterly data from the following two sources of OECD.StatExtract:

- We use the OECD Quarterly National Accounts data set (http://stats.oecd.org/ Index.aspx?DataSetCode=QNA, last visit September 2018) to obtain 'US dollars, volume estimates, fixed PPPs, OECD reference year, annual levels, seasonally adjusted' (VPVOBARSA) in order to calculate GDP growth rates.

- For the gross government debt ratio we use 'general government total gross debt, percentage of GDP at current prices and national currencies' (PCTGDPA) taken 
from OECD's Quarterly Public Sector Debt (http://stats.oecd.org/Index.aspx?

DataSetCode=QASA_TABLE7PSD, last visit September 2018).

We restrict our analysis to the same group of countries which results in a sample of 19 countries, given that there is no quarterly OECD debt data available for New Zealand. Please see Table B.1 for a summary statistic of both data sets.

Table B.1: Summary statistics

\begin{tabular}{ccccccc}
\hline \multirow{2}{*}{ Stats } & \multicolumn{2}{c}{ Period } & \multicolumn{2}{c}{ GDP Growth Rate } & \multicolumn{2}{c}{ Debt to GDP ratio } \\
& RR & OECD & RR & OECD & RR & OECD \\
\hline Min. : & 1946 & 1995 & -10.942 & -10.282 & 3.279 & 4.015 \\
1st Qu.: & 1963 & 2002 & 1.928 & 0.886 & 21.743 & 53.513 \\
Median: & 1979 & 2008 & 3.310 & 2.086 & 39.839 & 71.954 \\
Mean : & 1979 & 2007 & 3.428 & 1.924 & 45.389 & 82.233 \\
3rd Qu.: & 1994 & 2013 & 5.100 & 3.311 & 60.238 & 106.028 \\
Max. : & 2009 & 2018 & 27.329 & 29.119 & 247.482 & 240.149 \\
\hline
\end{tabular}

Notes: Corrected Reinhart and Rogoff (2010) data (referred to as RR in the table above) obtained by following Herndon et al. (2014) with $\tau=90, k=1$ left, quarterly OECD data (referred to as OECD) with $\tau=90, k=4$ right.

Country (obs.) Reinhart and Rogoff (2010) data: Australia (64), Austria (59), Belgium (63), Canada (64), Denmark (56), Finland (64), France (54), Germany (59), Greece (21), Ireland (63), Italy (59), Japan (54), Netherlands (53), New Zealand (61), Norway (64), Portugal (58), Spain (42), Sweden (64), United Kingdom (63), United States (64). Country (obs.) quarterly OECD data: Australia (93), Austria (73), Belgium (90), Canada (93), Denmark (73), Finland (73), France (70), Germany (78), Greece (73), Ireland (77), Italy (90), Japan (85), Netherlands (78), Norway (90), Portugal (78), Spain (90), Sweden (90), United Kingdom (93), United States (93). 


\section{Appendix C. Derivations}

We build on the argument developed in Domar (1944) who analyses the economic effect of sovereign debt. The debt-to-GDP ratio is given by the ratio of the growth rate of new debt, $d$, the constant GDP growth rate $G R$ as well as the constant inflation rate $\varphi$ as

$$
D:=\frac{D e b t}{G D P}=\frac{d}{G R+\phi}
$$

Looking at real GDP growth we impose $\varphi=0$ such that the log transformation of the above relationship can be estimated as

$$
\log (D)=\delta+\theta \log (G R)+v_{t}
$$

where $\delta=\log (d)$. Utilising Equation 1 while redefining both variables in its log form for the sake of readability, the OLS coefficient for D is defined as

$$
\hat{\beta} \rightarrow \frac{\operatorname{Cov}(G R, D)}{\operatorname{Var}(D)} .
$$

With $E\left[u_{t}\right]=E\left[v_{t}\right]=0$, and $E\left[u_{t}^{2}\right]=\sigma_{u}^{2} E\left[v_{t}^{2}\right]=\sigma_{v}^{2}, \hat{\beta}$ is unbiased only if $\theta=0$.

$$
\begin{aligned}
\operatorname{Cov}(G R, D) & =E([G R-E[G R]] \times[D-E[D]]) \\
& =E\left[\left[\beta v_{t}+u_{t}\right] \times\left[\theta u_{t}+v_{t}\right]\right] \\
& =E\left[\beta v_{t}^{2}+\theta u_{t}^{2}+\gamma v_{t} \theta u_{t}+u_{t} v_{t}\right] \\
& =\beta \sigma_{v}^{2}+\theta \sigma_{u}^{2} \\
\operatorname{Var}(D) & =E\left([D-E[D]]^{2}\right) \\
& =E\left(\left[\theta u_{t}+v_{t}\right]^{2}\right) \\
& =\theta^{2} \sigma_{u}^{2}+\sigma_{v}^{2}
\end{aligned}
$$

\section{Appendix D. Additional Figures}


Figure D.7: Individual Country plots of GDP Growth, Reinhart and Rogoff (2010), 1946 to 2009
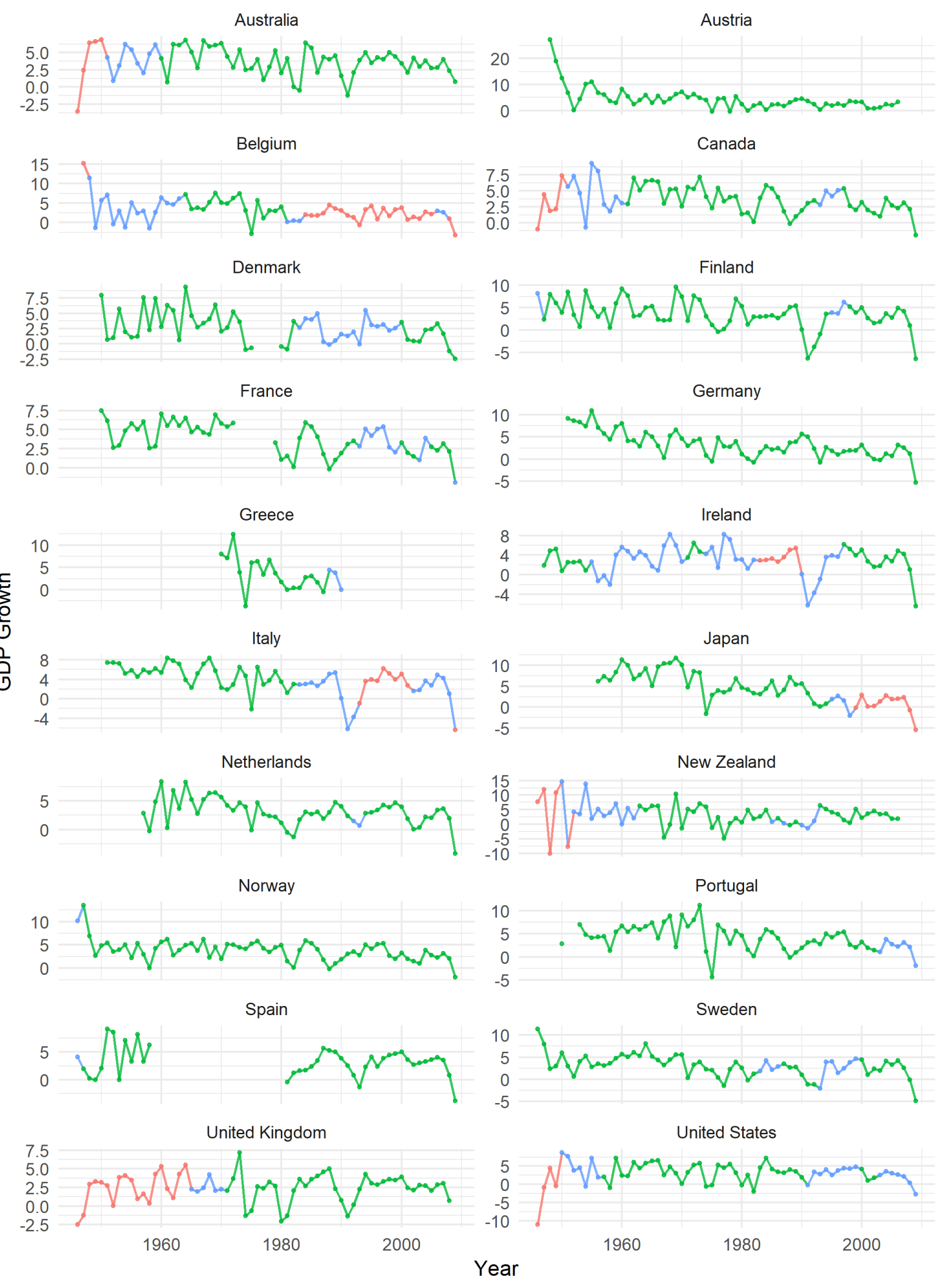

Gross Government Debt $\rightarrow$ above $90 \% \rightarrow$ between $60 \%$ and $90 \% \rightarrow$ below $60 \% \quad$ NA 
Figure D.8: Individual Country plots of debt-to-GDP ratio, Reinhart and Rogoff (2010), 1946 to 2009
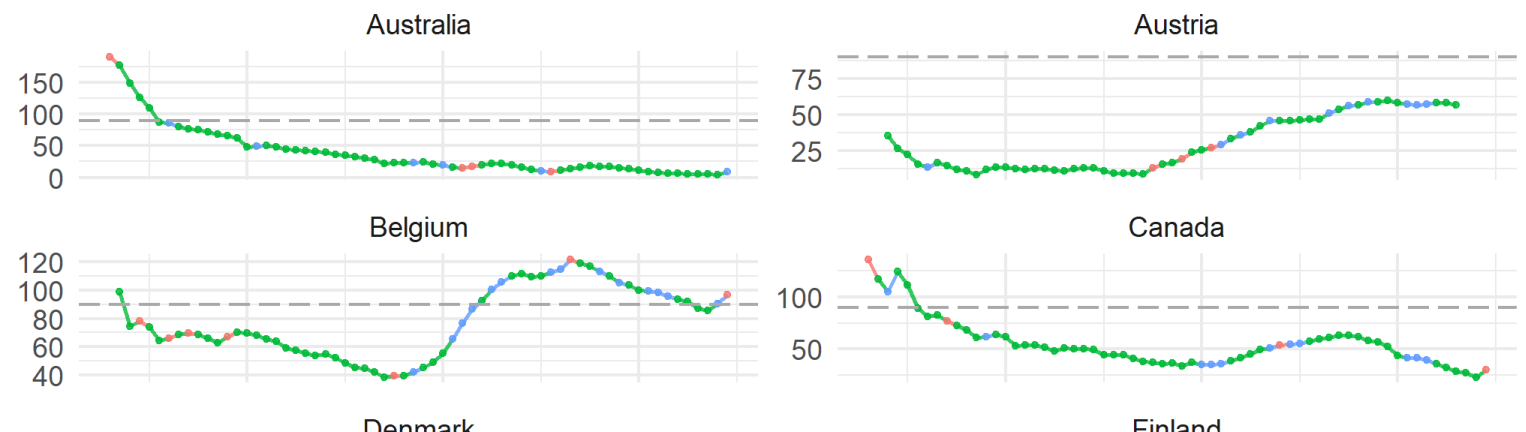

Finland
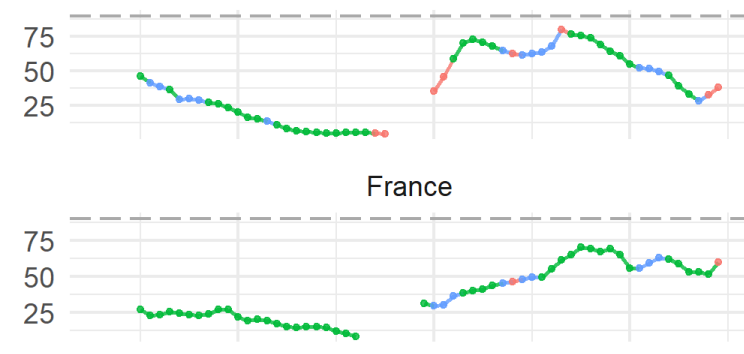

Greece
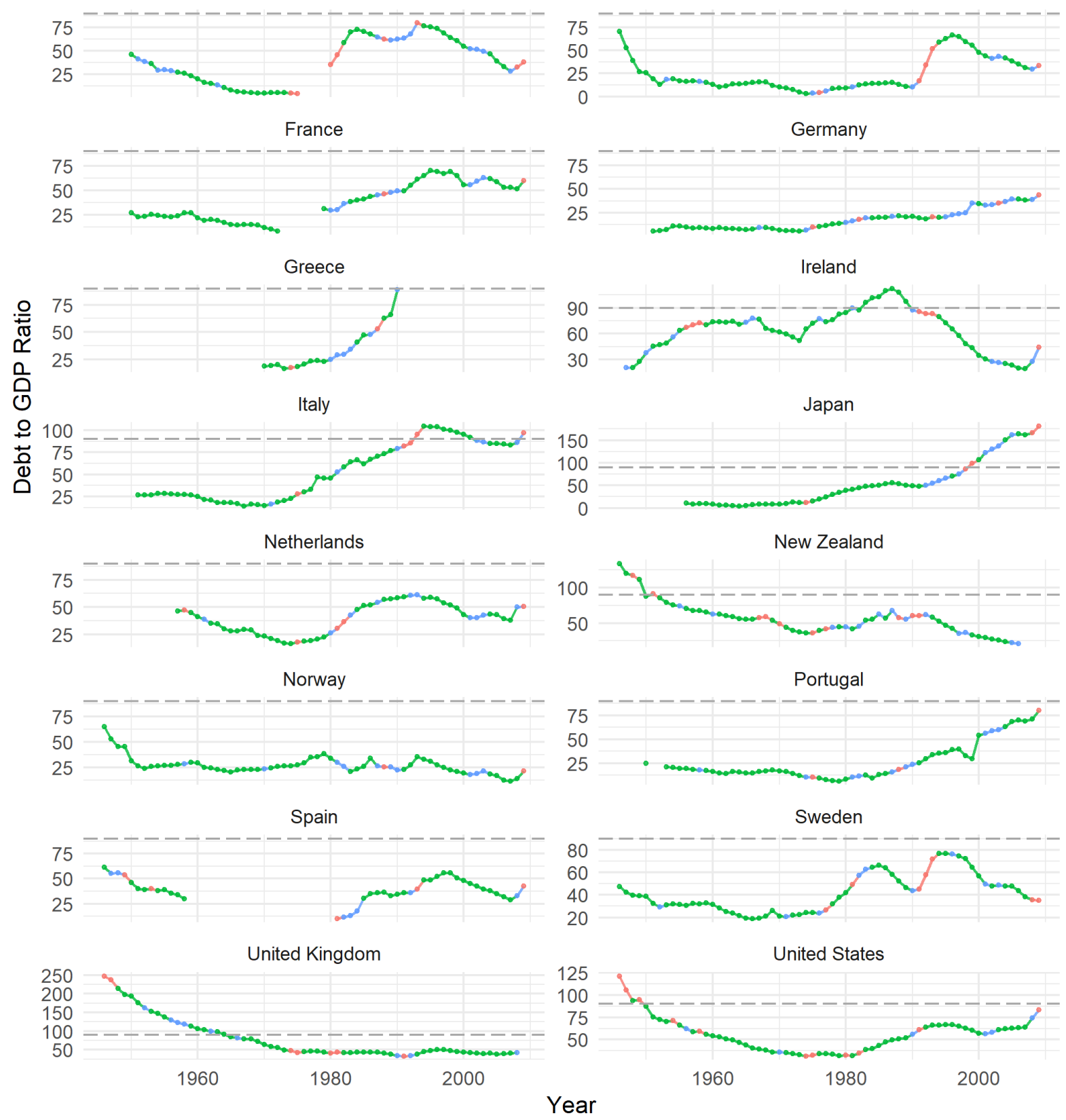

GDP Growth Rate $\rightarrow$ below $0 \% \rightarrow$ between $0 \%$ and $2 \% \rightarrow$ above $2 \%$

NA 
Figure D.9: Individual Country plots of GDP Growth, quarterly OECD data, 1996Q01 to 2018Q2
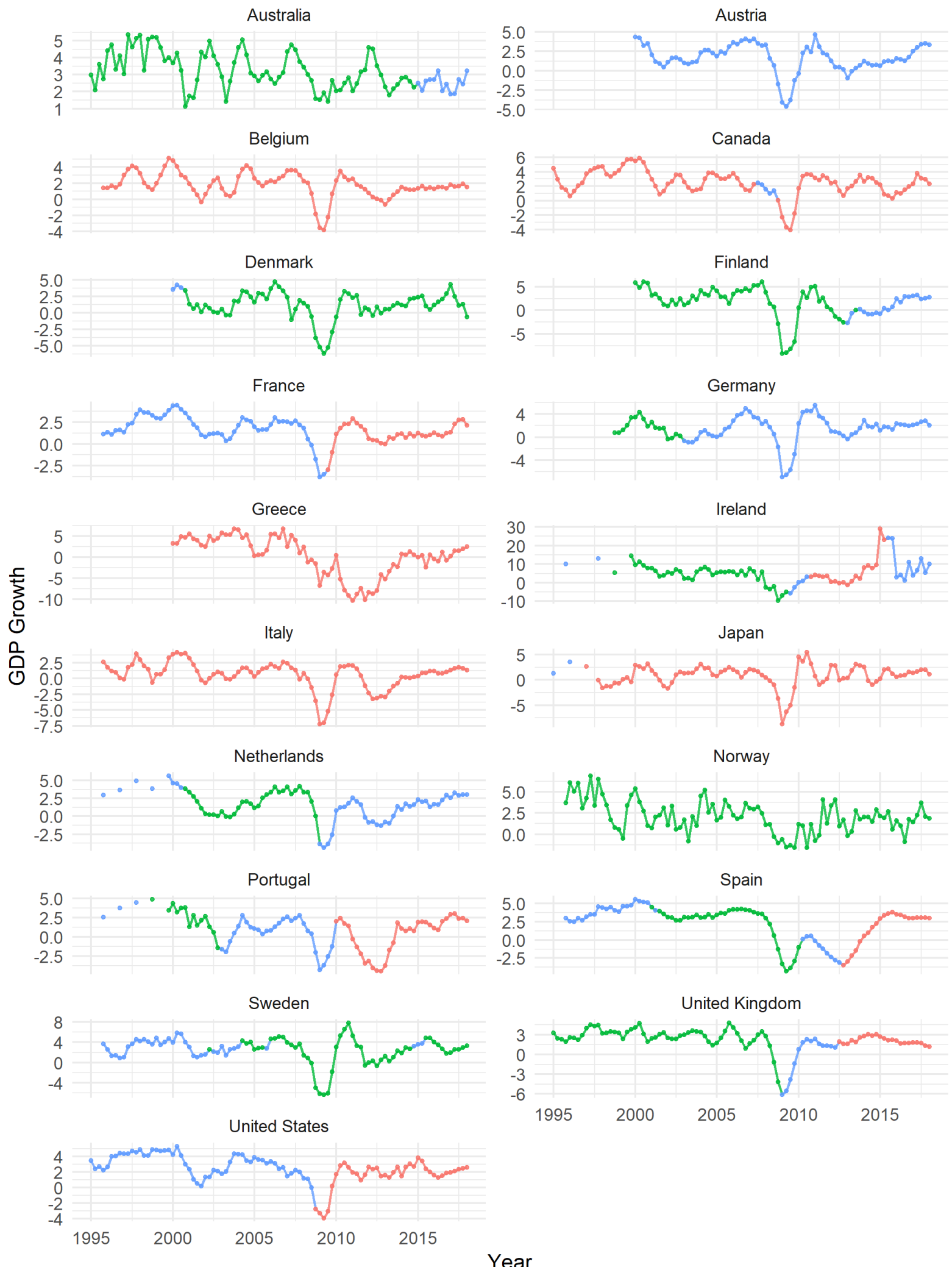
Figure D.10: Individual Country plots of debt-to-GDP ratio, quarterly OECD data, 1996Q01 to 2018Q2
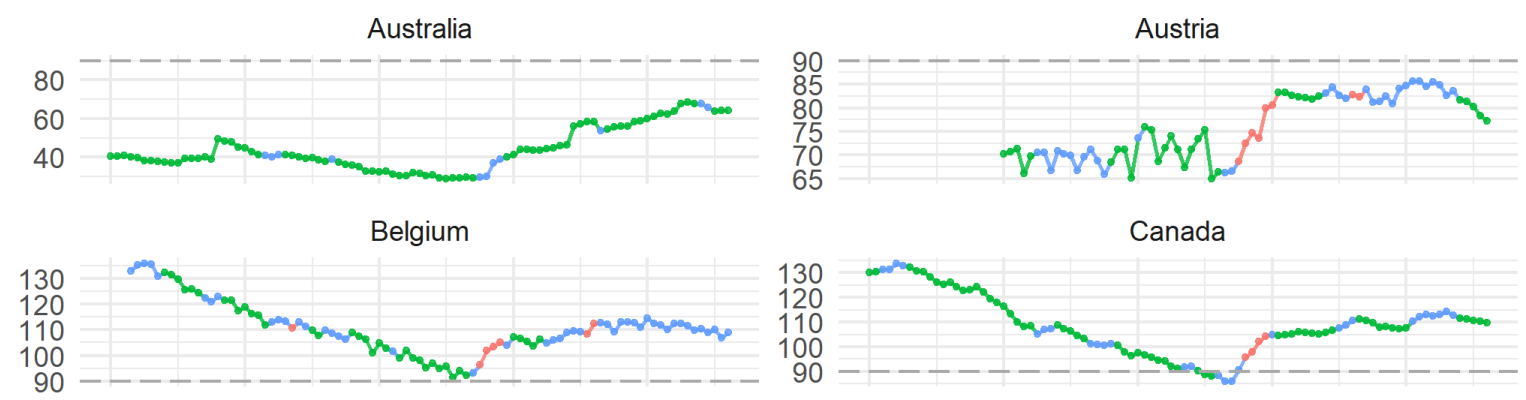

Denmark

Finland
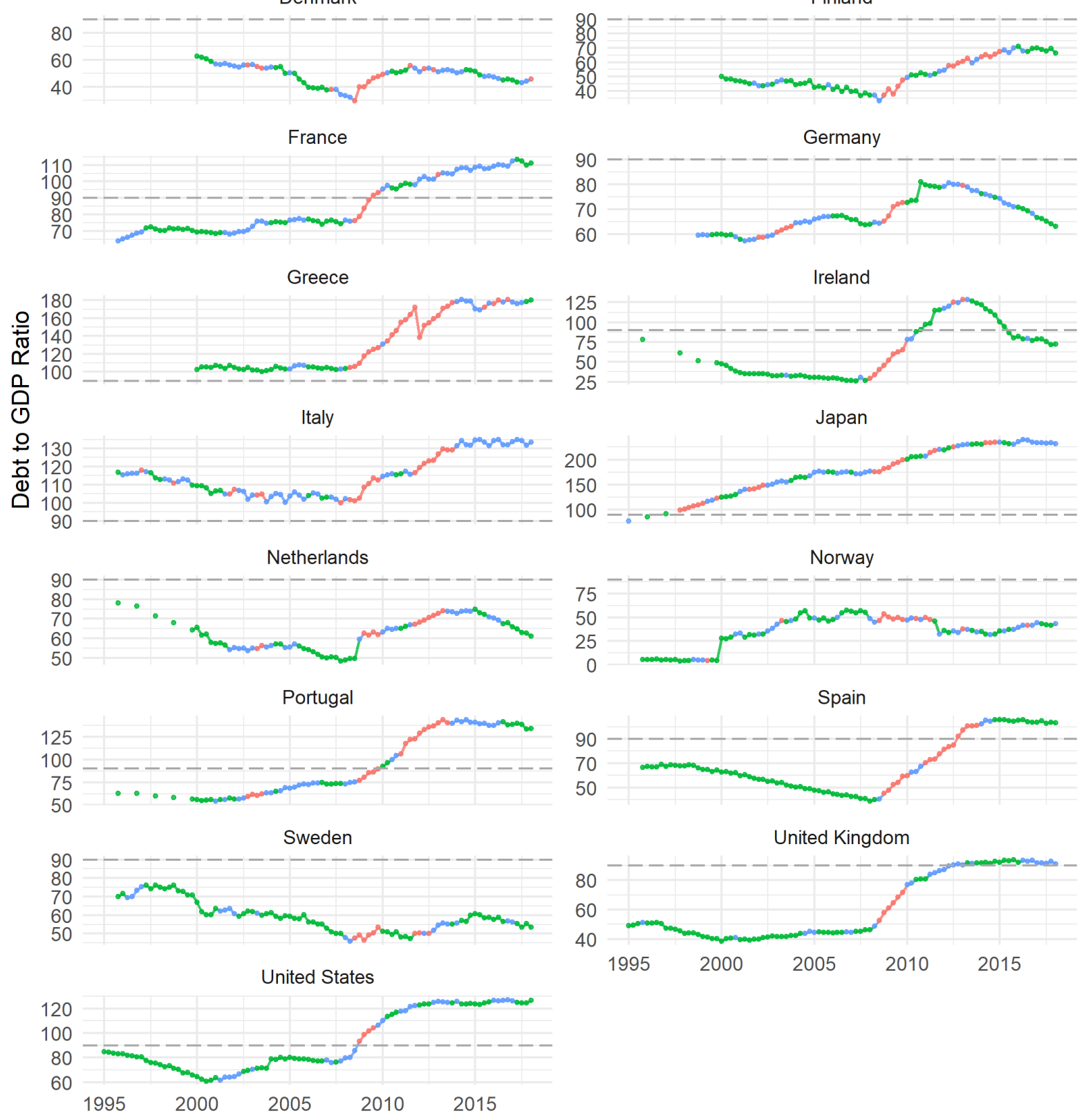

Year

GDP Growth Rate $\rightarrow$ below $0 \% \rightarrow$ between $0 \%$ and $2 \% \rightarrow$ above $2 \% \quad$ NA 